\title{
Associations between body condition score, locomotion score, and sensor-based time budgets of dairy cattle during the dry period and early lactation
}

\author{
P. R. Hut, ${ }^{1 *} \odot$ M. M. Hostens, ${ }^{1,2} \odot$ M. J. Beijaard, ${ }^{1} \odot$ F. J. C. M. van Eerdenburg, ${ }^{1} \odot$ J. H. J. L. Hulsen, ${ }^{3} \odot$ \\ G. A. Hooijer, ${ }^{1}$ (D) E. N. Stassen, ${ }^{4}$ and M. Nielen ${ }^{1}{ }^{1}$ \\ ${ }^{1}$ Department of Population Health Sciences, Division of Farm Animal Health, Faculty of Veterinary Medicine, Utrecht University, PO Box 80151 , \\ 3508 TD Utrecht, the Netherlands \\ ${ }^{2}$ Department of Reproduction, Obstetrics and Herd Health, Ghent University, Salisburylaan 133, Merelbeke 9820, Belgium \\ ${ }^{3}$ Vetvice/Cowsignals, 4614 PC Bergen op Zoom, the Netherlands \\ ${ }^{4}$ Adaptation Physiology Group, Department of Animal Sciences, Wageningen University \& Research, PO Box 338, 6700 AH Wageningen, \\ the Netherlands
}

\section{ABSTRACT}

Lameness, one of the most important disorders in the dairy industry, is related to postpartum diseases and has an effect on dairy cow welfare, leading to changes in cows' daily behavioral variables. This study quantified the effect of lameness on the daily time budget of dairy cows in the transition period. In total, 784 multiparous dairy cows from 8 commercial Dutch dairy farms were visually scored on their locomotion (score of 1-5) and body condition (score of 1-5). Each cow was scored in the early and late dry period as well as in wk 4 and 8 postpartum. Cows with locomotion scores 1 and 2 were grouped together as nonlame, cows with score 3 were considered moderately lame, and cows with scores 4 and 5 were grouped together as severely lame. Cows were equipped with 2 types of sensors that measured behavioral parameters. The leg sensor provided number of steps, number of stand-ups (moving from lying to standing), lying time, number of lying bouts, and lying bout length. The neck sensor provided eating time, number of eating bouts, eating bout length, rumination time, number of rumination bouts, and rumination bout length. Sensor data for each behavioral parameter were averaged between $2 \mathrm{~d}$ before and $2 \mathrm{~d}$ after locomotion scoring. The percentage of nonlame cows decreased from $63 \%$ in the early dry period to $46 \%$ at 8 wk in lactation; this decrease was more severe for cows with higher parity. Cows that calved in autumn had the highest odds for lameness. Body condition score loss of $>0.75$ point in early lactation was associated with lameness in wk 4 postpartum. Moderately lame cows had a reduction

Received July 2, 2020.

Accepted November 16, 2020.

*Corresponding author: P.R.Hut@uu.nl of daily eating time of around $20 \mathrm{~min}$, whereas severely lame cows had a reduction of almost 40 min. Similarly, moderately and severely lame dry cows showed a reduction of 200 steps/d, and severely lame cows in lactation showed a reduction of 600 steps/d. Daily lying time increased by $26 \mathrm{~min}$ and lying bout length increased by $8 \mathrm{~min}$ in severely lame cows compared with nonlame cows. These results indicate a high prevalence of lameness on Dutch dairy farms, with an increase in higher locomotion scores from the dry period into early lactation. Time budgets for multiparous dairy cows differed between the dry period and the lactating period, with a higher locomotion score (increased lameness) having an effect on cows' complete behavioral profile. Body condition score loss in early lactation was associated with poor locomotion postpartum, whereas lameness resulted in less eating time in the dry period and early lactation, creating a harmful cycle.

Key words: dairy cow, lameness, locomotion score, sensor data, transition period

\section{INTRODUCTION}

Lameness remains an underestimated problem in the dairy industry even as researchers have demonstrated that it affects a large percentage of dairy cows (Somers et al., 2003; Holzhauer et al., 2006; Bicalho et al., 2009). Lameness is usually caused by claw disorders (Barker et al., 2010; Solano et al., 2015; Randall et al., 2019) that are often painful (O'Callaghan et al., 2003; Bruijnis et al., 2012) and is associated with or followed by other diseases (Hernandez et al., 2002). However, claw disorders are not always clearly associated with lameness because cows are stoic prey animals (Blackie et al., 2013) and often mask the experience of pain until it is severe (O'Callaghan et al., 2003; Dyer et al., 2007). In addition to the effect on animal welfare, lameness is 
associated with economic losses (Enting et al., 1997), an increase in culling rates, and a reduction in milk yield and has an effect on fertility (Green et al., 2002; Melendez et al., 2003; Amory et al., 2008).

A practical method to detect lameness is visual locomotion scoring. A locomotion score uses a scale of 1 to 5 to show differences between nonlame and lame cows, where 1 is a nonlame cow and 5 is a severely lame cow (Sprecher et al., 1997). Important factors that affect locomotion score are type, hardness, and slipperiness of the walking surface (van der Tol et al., 2005; Alsaaod et al., 2017; Telezhenko et al., 2017). These circumstances could result in a score related to mild lameness when a nonlame cow is actually just walking cautiously.

While lameness obviously affects a cow's movement (O'Callaghan et al., 2003), it also affects a range of other types of behavior. Lameness was reported to be associated with variations in feeding behavior: less eating time but unaltered rumination time compared with nonlame cows (Thorup et al., 2016; Weigele et al., 2018). Other studies showed lower rumination time in new cases of lameness or variations in rumination time related to lameness (Steensels et al., 2017; King et al., 2018). Lame cows also showed longer lying times, fewer but longer lying bouts, and a higher variation in lying bout length (Chapinal et al., 2009; Ito et al., 2010; Solano et al., 2016). Thus, lameness most likely affects the daily time budget or behavioral patterns of dairy cows. It is not the sole factor, given that the time budget of transition cows differs pre- and postpartum (Kok et al., 2017; Hut et al., 2019), mainly due to the daily milking routine postpartum.

Others have studied the time budget of moderately lame cows on farms with sand or mattresses (Cook et al., 2004; Gomez and Cook, 2010); however, a complete sensor-based behavioral profile or time budget based on feeding, lying, and walking behavior in relation to lameness seems lacking. A recent longitudinal study showed vulnerability to lameness to be highly related to previous cases of lameness (Randall et al., 2018), but these researchers did not analyze the transition period, when cows are generally more vulnerable to health problems (Drackley, 1999). The dry period has been identified as a time when cows are especially vulnerable to developing lameness. Cows with a low BCS at dry off had higher odds of chronic lameness in the dry period and less cure from lameness (Daros et al., 2019). Loss of BCS in the dry period was shown to be a predisposing factor for transition disease and for reduced productive and reproductive parameters postpartum, but not for lameness (Chebel et al., 2018; Daros et al., 2020). Based on scoring BCS weekly in one herd and every 60 $\mathrm{d}$ in another herd, corrected for previous lameness, a
BCS of $<2.25$ and $<2$, respectively, was associated with higher odds for lameness 1 to 3 wk or up to 4 mo later (Randall et al., 2018).

Therefore, the goal of this study is 2-fold. The first is to use locomotion scores to get insight into the prevalence of high locomotion scores from the onset of the dry period until $8 \mathrm{wk}$ in lactation as well as the association with BCS and changes in BCS. The second is to quantify the effect of impaired locomotion on a daily time budget including parameters for feeding, lying, and walking behavior of dairy cows in the dry period and early lactation.

\section{MATERIALS AND METHODS}

\section{Farms and Animals}

This study was conducted from November 1, 2016, to May 1, 2018, and included 1,326 dairy cows on 8 commercial dairy farms with freestall barns in the Netherlands. Details of these farms regarding herd size, type of bedding, type of milking system, production level, pasture access, and average dry period length are presented in Table 1. All farms had separate far-off and close-up groups in the dry period and 1 lactational group for all cows in milk. Primiparous cows $(\mathrm{n}=303)$ were excluded from this study because these animals do not have a transition period and because of behavioral differences compared with multiparous cows in the transition period (Hut et al., 2019). Some cows were excluded because their data were incomplete; analysis required 4 consecutive locomotion and body condition scores and a selection for complete sensor data for $\mathrm{d}$ $-2,-1,+1$, and +2 relative to the day of scoring. Analysis included data of 784 multiparous cows. The numbers of cows per sensor-based behavior output are presented in Figure 1.

\section{Sensors}

To measure feeding behavior, commercially available Nedap Smarttag Neck sensors (Nedap, Groenlo, the Netherlands) were attached to the neck collar of the cows, and commercially available Nedap Smarttag Leg sensors were attached to one of the front legs of the cows to measure walking and lying behavior. The Nedap Smarttag sensors use G-sensors, which use acceleration as a measure of movement and the $x^{-}, y_{-}^{-}$, and z-axes (3-dimensional space) to determine the angle. A proprietary neural network was used to determine whether the cow was displaying the specified behavior per minute. Behavioral parameters were recorded each minute within every 15-min period of each day (Van 


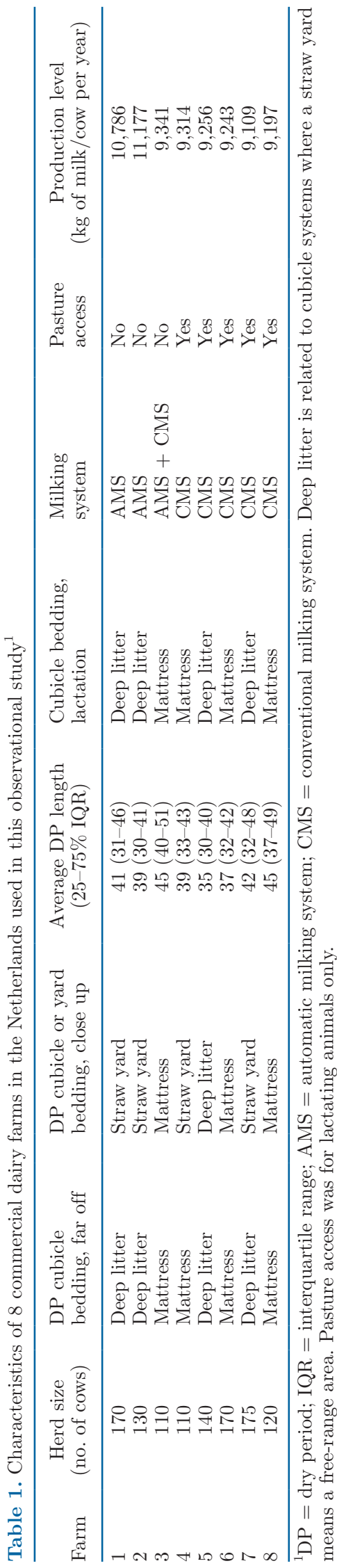

Erp-Van der Kooij et al., 2016). The daily number of eating and rumination bouts was also measured by the neck sensor, as was the average duration per eating and rumination bout. Through the leg sensor, the number of steps, number of stand-ups (moving from lying to standing), lying time, number of lying bouts, and duration per lying bout were measured (Nielsen et al., 2018).

\section{Study Design}

At the beginning of the dry period, the end of the dry period, 4 wk postpartum, and 8 wk postpartum, a trained veterinarian $(\mathrm{PH})$ visually scored cows from all 8 herds for their locomotion score and BCS. Every scoring event was conducted on slatted concrete floors. Scoring took place in freestall systems where every cow was scored individually to assign a body condition and a locomotion score without any interference from milking routines. The distribution of all locomotion scores per farm and per scoring event of all multiparous cows with 4 consecutive scores is presented in Table 2. Because of the final numbers of cows per locomotion score, cows with locomotion scores 1 and 2 were grouped together as nonlame, cows with score 3 were considered moderately lame, and cows with scores 4 and 5 were grouped together as severely lame. Sensor data from both sensors of every cow and every scoring event were collected from $7 \mathrm{~d}$ before until $7 \mathrm{~d}$ after every scoring event. Sensor data from the day of scoring were excluded from the analysis because of possible bias caused by the data collection during locomotion scoring. To exclude days where cows were still being milked to evaluate the early dry period and to exclude days where cows were already milked to evaluate the late dry period, only sensor data of $2 \mathrm{~d}$ before $(\mathrm{d}-2)$ and $2 \mathrm{~d}$ after $(\mathrm{d}+2)$ locomotion scores were used and averaged per day for analysis. These $4 \mathrm{~d}$ around locomotion scoring were considered to represent precisely the daily time budget as affected by the potential lameness.

Body condition score was determined on a scale of 1 to 5 with 0.25-point increments (Ferguson et al., 1994) and was categorized into 3 groups based on $33 \%$ and $66 \%$ percentile values. These groups were $<2.75$, 2.75 to 3.25 , and $>3.25$ for the early dry period; $<3.0$, 3.0 to 3.5 , and $>3.5$ for the end of the dry period; $<2.5,2.5$ to 3.0 , and $>3.0$ for wk 4 ; and $<2.25,2.25$ to 2.75 , and $>2.75$ for wk 8 . Changes in BCS were defined for 3 intervals: from the early dry period to the end of the dry period, from the end of the dry period to wk 4 postpartum, and from wk 4 postpartum to wk 8 postpartum. The BCS change in the dry period (change dry) was categorized into 3 groups based on $33 \%$ and $66 \%$ percentile values as follows: BCS decrease 
$(>0.00)$, a slight increase $(0.00-0.25)$, and a moderate increase $(>0.25)$. From the end of the dry period to 4 wk postpartum (change transition), BCS change was categorized as a severe decrease $(>0.75)$, a moderate decrease $(0.50-0.75)$, or a slight decrease $(<0.50)$. From
4 to 8 wk postpartum (change post), BCS change was categorized as a moderate decrease $(>0.25)$, a slight decrease $(<0.25)$, or an increase $(>0.00)$.

Calving season was modeled according to Sanders et al. (2009) with 3 mo per season (winter, spring, sum-

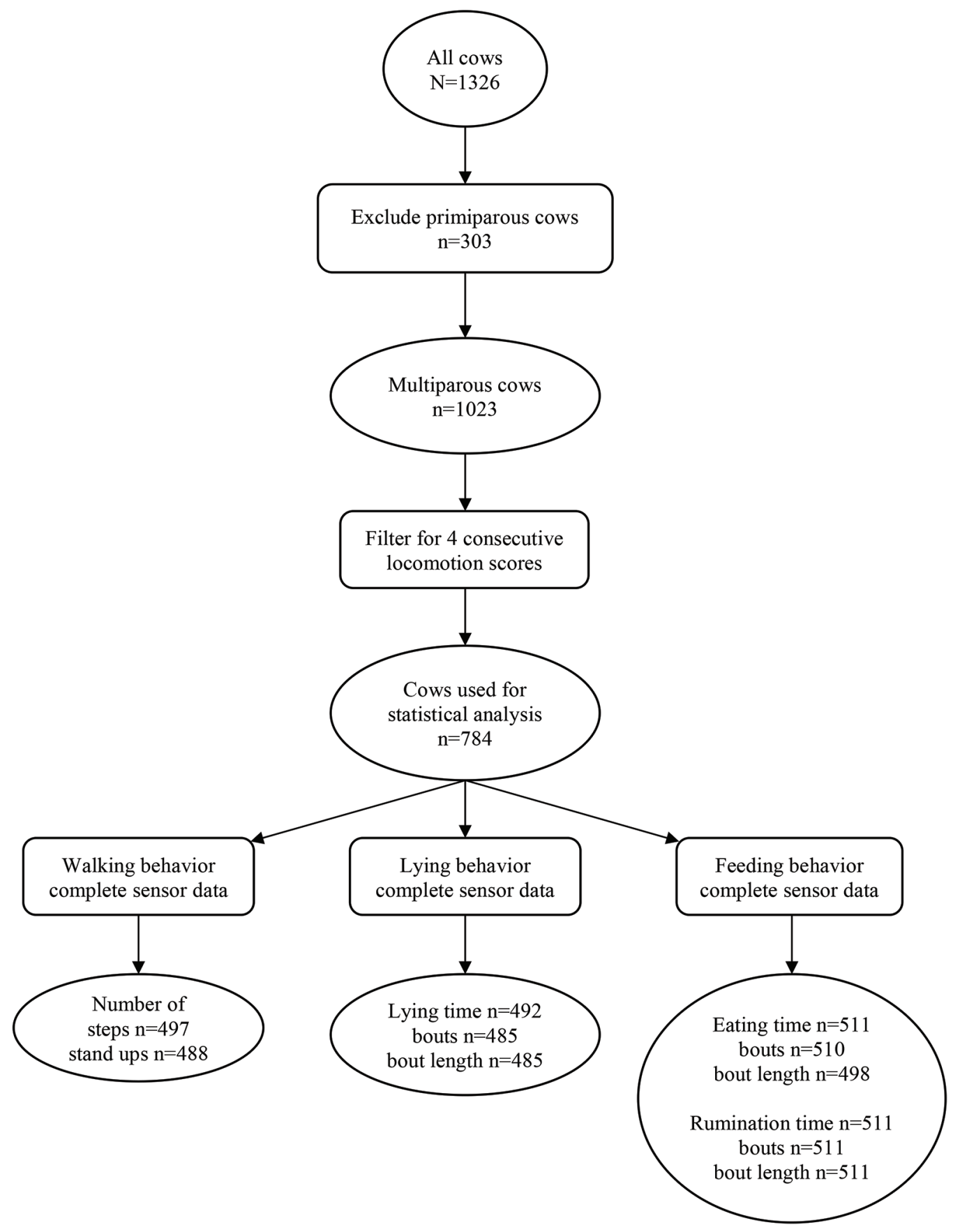

Figure 1. Selection process of cows used for analysis in this study. Starting with 1,326 cows in total, 303 primiparous cows were excluded; 1,023 multiparous cows remained and were filtered for 4 consecutive locomotion scoring events, which resulted in 784 cows. Further selection was based on available sensor data for $\mathrm{d}-2$ and $\mathrm{d}+2$ relative to the day of scoring (complete sensor data of $4 \mathrm{~d}$ ). 
mer, and autumn). For example, January to March was considered to be winter.

The dry period length was based on the number of days between the first scoring event in the early dry period and the calving date. The dry period length was categorized into 3 equally distributed groups based on $33 \%$ and $66 \%$ percentiles as follows: $<34 \mathrm{~d}, 34$ to $43 \mathrm{~d}$, and $>43 \mathrm{~d}$.

\section{Statistical Analysis}

All analyses were performed using $\mathrm{R}$ ( $\mathrm{R}$ Core Team, 2019) version 3.6.1, including packages "Ime4" (Bates et al., 2015), "magrittr" (Bache and Wickham, 2014), "dplyr" (Wickham et al., 2018), "tidyr" (Wickham and Henry, 2019), "multcompView" (Graves et al., 2019), "data.table" (Dowle and Srinivasan, 2019), "Ismeans"

Table 2. Distribution of locomotion scores per farm and scoring event of all multiparous cows with 4 consecutive scores

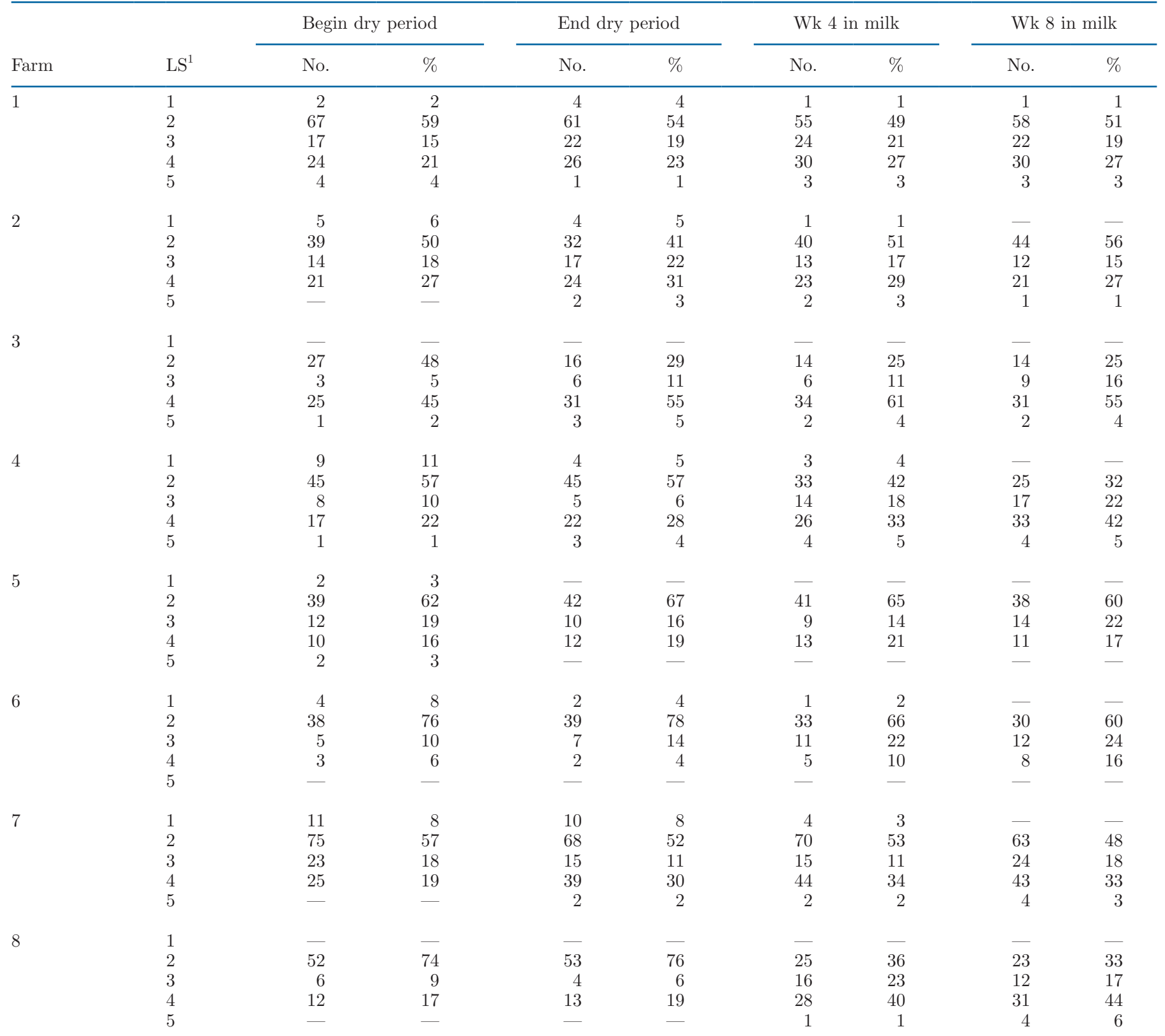

${ }^{1}$ Locomotion score. Each cow was scored in the early and late dry periods as well as in wk 4 and 8 postpartum. Cows with locomotion scores 1 and 2 were grouped together as nonlame, cows with score 3 were considered moderately lame, and cows with scores 4 and 5 were grouped together as severely lame. 
(Lenth, 2016), "effects" (Fox and Weisberg, 2018), "car" (Fox and Weisberg, 2011), "ggplot2" (Wickham, 2016), and "ggpubr" (Kassambara, 2018). All statistical analyses including code scripts can be downloaded at https://github.com/Bovi-analytics/Hut-et-al-2020. Descriptive visuals can be downloaded at https:// public.tableau.com/profile/bovianalytics\#!/vizhome/ Hutetal_2020/TransitionBodyConditionScore. The univariable analyses and final reduced models are presented in Appendix Tables A1 and A2. Differences between lameness prevalences, defined as scores 3, 4, and 5 combined, were tested by chi-squared test for the contrast dry versus lactating and Bonferroni corrected for the 4 scoring events against each other.

\section{Association Models}

For the association between BCS and lameness, 2 generalized linear mixed (binomial family with logit link) models were created for the locomotion scores at wk 4 and 8 comparing "healthy 1-2" versus "lame 3-5," "healthy 1-2" versus "lame 4-5," and "healthy 1-2-3" versus "lame 4-5." Only results from the first analysis ("healthy 1-2" vs. "lame 3-5") are presented because results were comparable. Initially, all individual explanatory variables were tested in univariable models with herd as random effect. Only variables with $P<$ 0.1 were further analyzed in a multivariable model, including their mutual interactions. Thereafter, the likelihood ratio test on the Akaike information criterion was performed for model reduction to determine which final reduced model fitted the data best using the drop1 function. Final model effects were reported as odds ratios based on profile likelihoods. Multicollinearity was assessed with the variance inflation factor. There was no evidence of multicollinearity because every variance inflation factor value was $<10$ (Dohoo et al., 2003). Differences were reported with $P$-values, where $P<0.05$ was deemed significant and $P<0.1$ a trend.

\section{Sensor Data Models}

All behavioral parameters were first checked for normal distribution and for linearity with quantile-quantile plotting. Except for the number of steps, all behavioral parameters displayed a normal distribution. To correct for skewness in the model concerning the number of steps, data were first $\log$ transformed and the final models were back transformed.

Generalized linear mixed models with a normal distribution were used for statistical analysis per behavioral parameter, corrected for animal within herd as random effect. Initially, individual explanatory variables farm, calving season, and parity were tested in univariable models with animal within herd as random effect. Furthermore, the 3-way interaction between locomotion score, observation period (prepartum and postpartum), and observation event [begin dry (first score prepartum), end dry (second score prepartum), $4 \mathrm{wk}$ in milk (first score postpartum), and $8 \mathrm{wk}$ in milk (second score postpartum)] was offered. Thereafter, the likelihood ratio test on the Akaike information criterion was performed for full model reduction to determine which reduced model fitted the data best using the drop1 function. Farm and parity remained or were forced in all models. Final model effects were reported as means with $95 \%$ confidence intervals based on profile likelihoods. Differences between means were reported with $P$-values, where $P<0.05$ was deemed significant and $P<0.1$ a trend.

\section{RESULTS}

\section{Descriptives}

The distribution of locomotion scores per scoring event is presented in Figure 2A and shows the percentage of cows per locomotion score event. The percentage of locomotion scores per parity 2,3 , and $>3$ per scoring event is presented in Figure 2B. The lameness percentages (locomotion scores 3,4 , and 5 combined) increased from $36 \%$ in the early dry period to $41 \%$ in the late dry period, $51 \%$ at 4 wk postpartum, and $54 \%$ at 8 wk postpartum. The percentages were different between the dry and lactation periods $(P<0.001)$ as well as between the beginning of the dry period versus 4 wk postpartum $(P<0.001)$, the beginning of the dry period versus 8 wk postpartum $(P<0.001)$, the end of the dry period versus 4 wk postpartum $(P=0.006)$, and the end of the dry period versus 8 wk postpartum $(P<0.001)$.

The categorized distribution of BCS per scoring event is presented in Figure 3A. The categorized change of the BCS between scoring events is presented in Figure 3B. In general, the BCS distributions indicate an increase in BCS during the dry period, a loss in BCS between the end of the dry period and $4 \mathrm{wk}$ postpartum, and a more or less equal distribution between cows losing and increasing in BCS between 4 and 8 wk postpartum.

The descriptive patterns of 2 sensor-based behavioral parameters are shown in Figure 4. These include the daily number of steps from the leg sensor and daily eating time from the neck sensor from $\mathrm{d}-7$ to $\mathrm{d}+7$ around locomotion scoring (d 0 ). Other behavioral parameters from the leg sensor [stand-ups (no./d), lying time $(\mathrm{min} / \mathrm{d})$, lying bouts (no./d), and lying bout length (min/bout)] are presented in Appendix Figure A1A. The remaining neck sensor variables [eating 
A

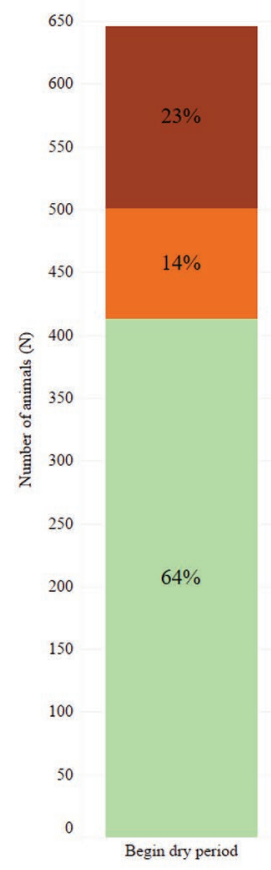

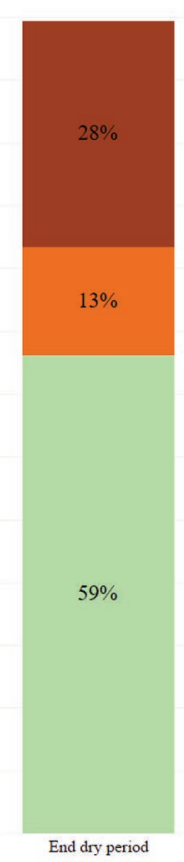

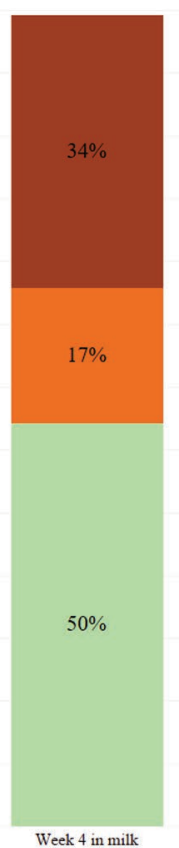

B

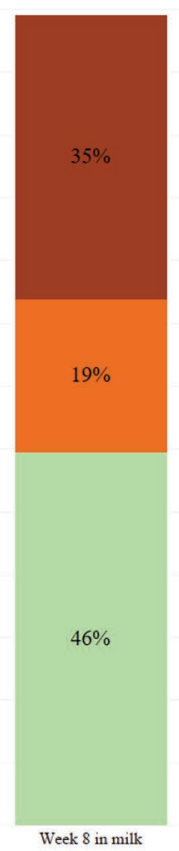

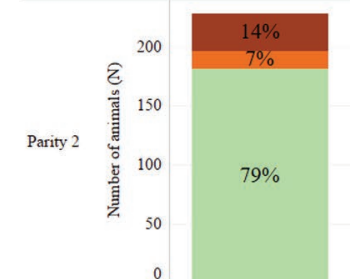
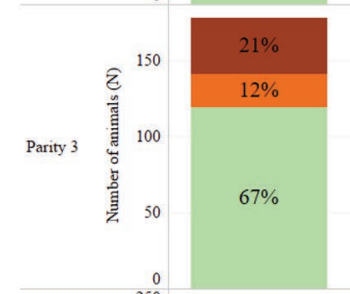
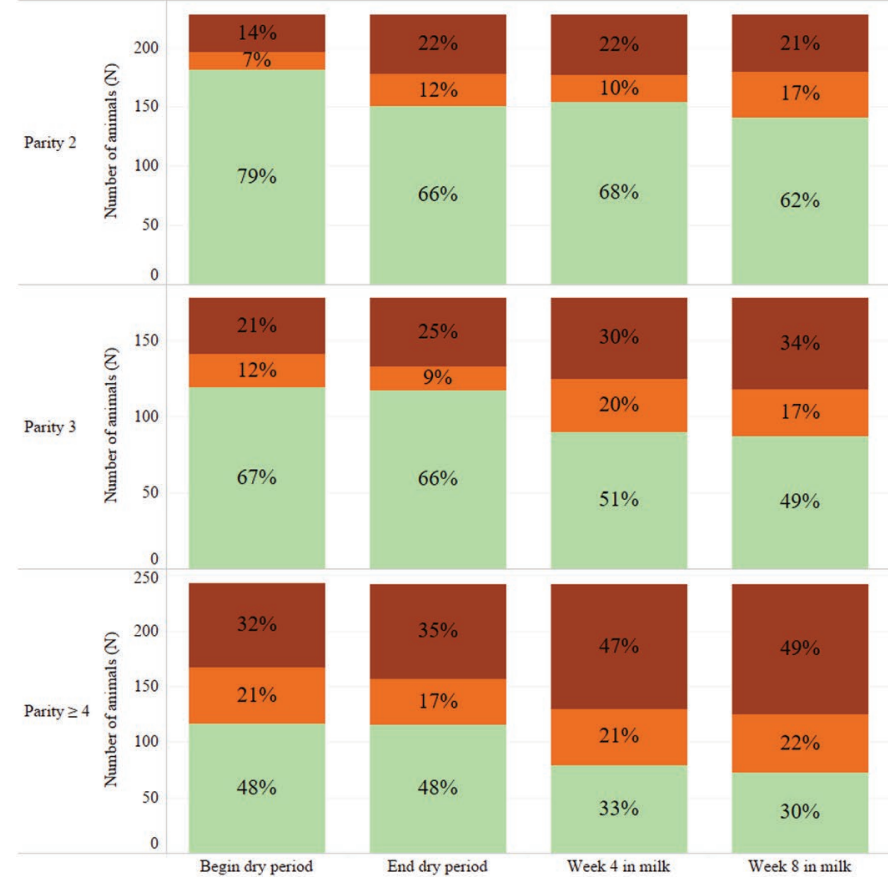

Figure 2. Distribution of multiparous cows (in \%) with 4 consecutive scorings per locomotion score per scoring event (begin dry, end dry, 4

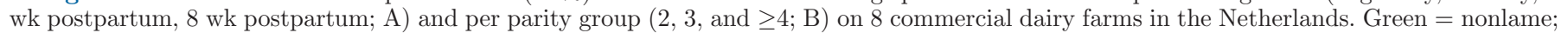
orange $=$ moderately lame; red = severely lame.

bouts (no./d), eating bout length ( $\mathrm{min} /$ bout), rumination time $(\mathrm{min} / \mathrm{d})$, rumination bouts (no./d), and rumination bout length (min/bout)] are presented in Appendix Figure A1B. The descriptive patterns of eating time and number of steps around the 4 scoring events for nonlame cows per farm are illustrated in Appendix Figure A2 to present the baseline of nonlame cows and to show numerical differences in behavior in the dry and lactational periods.

\section{Association Models}

The final reduced models are presented in Table 3. The final model for wk 4 included parity, calving season, and change in BCS between the end of the dry period and wk 4 postpartum (change transition). Cows with a large decrease in BCS of $>0.75$ point from the end of the dry period until 4 wk postpartum (change transition) had higher odds (1.76) for lameness compared with cows with a decrease of $<0.50(P=0.048)$. Cows calving in autumn had higher odds of being lame in wk 4 postpartum than cows calving in summer, winter, and spring. An increasing parity resulted in increasing odds for lameness in wk 4 postpartum.

The final model for wk 8 included only calving season and parity (Table 3 ). Cows calving in autumn and sum- mer had higher odds of being lame in wk 8 postpartum than cows calving in winter and spring. An increasing parity resulted in increasing odds for lameness in wk 8 postpartum.

\section{Sensor Data Models}

The statistical analysis showed that the overall time budget of dairy cows differed between the dry period and early lactation; these results are presented in Table 4. All significant effects relative to nonlame cows are described per sensor-based behavioral parameter. First, as the model of the number of steps per day per locomotion score group ( 1 and $2=$ nonlame; $3=$ moderately lame; 4 and $5=$ severely lame) shows, there was a significant difference between the dry and lactational periods. The daily number of steps declined by more than 200 steps for moderately and severely lame dry cows. In lactation, the number of steps declined by more than 600 steps for severely lame cows (Figure 5A). Severely lame cows had 26 min more lying time irrespective of the dry and lactating periods (Figure 5B). The number of lying bouts is shown in Figure 5C; there were significant differences between the dry and lactating periods, with 0.2 fewer lying bouts for severely lame cows in the lactating period. Lying bout length (Figure 
A

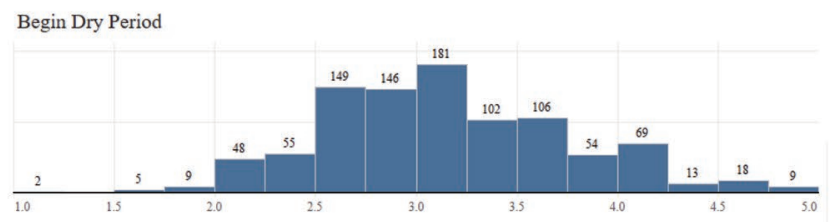

End Dry Period

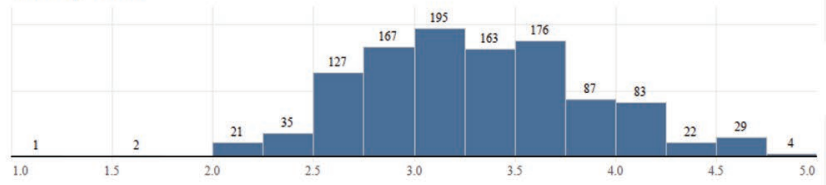

Week 4 in milk

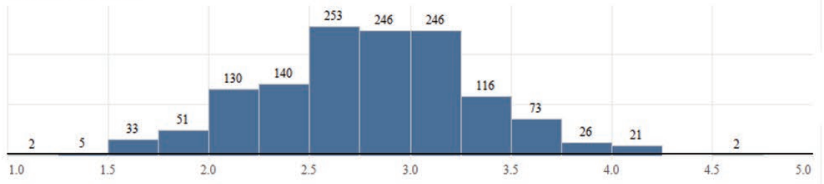

Week 8 in milk

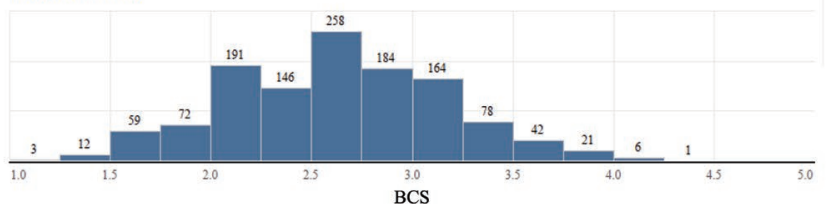

B

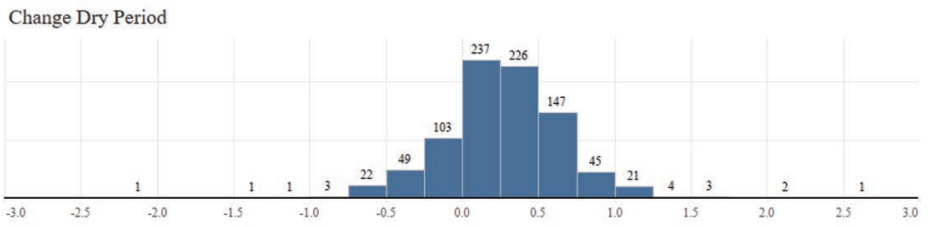

Change Transition

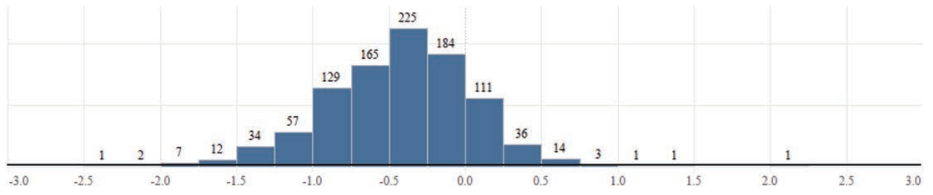

Change Postpartum

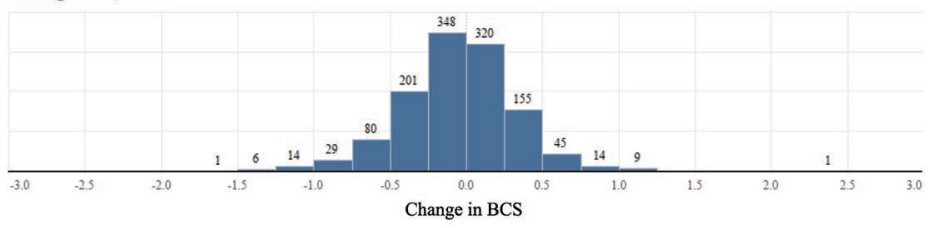

Figure 3. Distribution of the BCS of multiparous cows with 4 consecutive scorings per scoring event (begin dry, end dry, 4 wk postpartum,

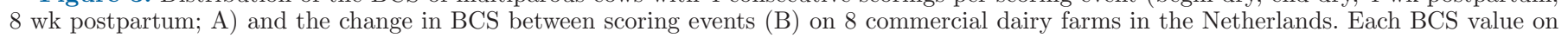
the $\mathrm{x}$-axis corresponds with the bar to the left of that value.

5D) increased in severely lame cows; their lying bouts were 8 min longer, with no additional effect from dry or lactating period.

Eating time (Figure 6A) was lower in moderately lame and severely lame cows. Moderately lame cows spent 20 min less per day eating, and severely lame cows spent 38 min less in both the dry and lactational periods. For number of eating bouts, moderately lame cows show a trend of 0.4 fewer eating bouts, and severely lame cows had 0.8 fewer eating bouts per day in lactation (Figure 6B). The length of eating bouts (Figure 6C) was irrespective of the dry and lactational periods and was shorter in moderately lame cows (1.4 min less per bout) and severely lame cows (2.3 min less per bout). The rumination bout length (Figure 6D) was 1.1 min shorter for moderately lame dry cows and 1.4 min shorter for severely lame dry cows.

\section{DISCUSSION}

The locomotion scoring system (Sprecher et al., 1997) is a subjective scoring method with inter- and intraobserver variation (Channon et al., 2009). A limitation of our study is the unknown intraobserver reliability of the single scorer, which may have resulted in relatively low numbers of cows with scores 1 and 5. Therefore, cows with scores 1 and 2 were combined, as were cows with scores 4 and 5; cows with score 3 were studied separately. The low number of cows with score 1 could be due to all cows having been scored on concrete slatted floors. Concrete is not their ideal walking surface and seems less suitable for claw health compared with straw yards (van der Tol et al., 2005; Frankena et al., 2009). Although this recoding excluded the possibility of estimating the effect of each distinct score, our results indicate an effect on daily time budget with significant and biologically plausible differences. This is mainly the case for daily eating time, lying time, and number of steps. In contrast to the study of Grimm et al. (2019), which grouped locomotion scores 1, 2, and 3 together as nonlame and scores 4 and 5 together as lame, our study also showed behavioral differences between scores 1 and 2 and score 3 .

Impaired locomotion increased for multiparous cows in lactation groups $\geq 3$ from the early dry period until 8 wk postpartum, showing a large decrease in nonlame cows, especially after calving (Figure 2). The increasing number of lame and severely lame cows during the 4 scoring events could be related to the presence of chronic claw disorders (Bruijnis et al., 2012). The 
Table 3. Reduced final logistic regression models for the association between lameness at wk 4 and 8 postpartum [lame (scores 3, 4, and 5) vs. nonlame (scores 1 and 2)] and recoded BCS with calving season, parity, and dry period length as fixed effects and herd as random effect

\begin{tabular}{|c|c|c|c|c|}
\hline Variable & Estimate & SE & Odds ratio & $P$-value \\
\hline \multicolumn{5}{|l|}{ Wk 4} \\
\hline \multicolumn{5}{|l|}{ BCS change transition } \\
\hline Decrease $<0.50$ & Ref. ${ }^{1}$ & & & \\
\hline Decrease $0.50-0.75$ & 0.3018 & 0.1933 & 1.35 & 0.1185 \\
\hline Decrease $>0.75$ & 0.5659 & 0.2343 & 1.76 & 0.0156 \\
\hline \multicolumn{5}{|l|}{ Calving season } \\
\hline Autumn & Ref. & & & \\
\hline Summer & -0.8321 & 0.2320 & 0.44 & 0.002 \\
\hline Winter & -0.9744 & 0.2353 & 0.38 & $<0.001$ \\
\hline Spring & -1.5533 & 0.2788 & 0.21 & $<0.001$ \\
\hline \multicolumn{5}{|l|}{ Parity } \\
\hline 2 & Ref. & & & \\
\hline 3 & 0.6189 & 0.2111 & 1.86 & 0.0033 \\
\hline$\geq 4$ & 1.3732 & 0.2037 & 3.95 & $<0.001$ \\
\hline \multicolumn{5}{|l|}{ Wk 8} \\
\hline \multicolumn{5}{|l|}{ Calving season } \\
\hline Autumn & Ref. & & & \\
\hline Summer & -0.2903 & 0.2277 & 0.75 & 0.2024 \\
\hline Winter & -1.0419 & 0.2415 & 0.35 & $<0.001$ \\
\hline Spring & -1.3572 & 0.2676 & 0.26 & $<0.001$ \\
\hline \multicolumn{5}{|l|}{ Parity } \\
\hline 2 & Ref. & & & \\
\hline 3 & 0.5204 & 0.2142 & 1.68 & 0.01 \\
\hline$\geq 4$ & 1.4659 & 0.2072 & 4.33 & $<0.001$ \\
\hline
\end{tabular}

${ }^{1}$ Referent.

Sensor values

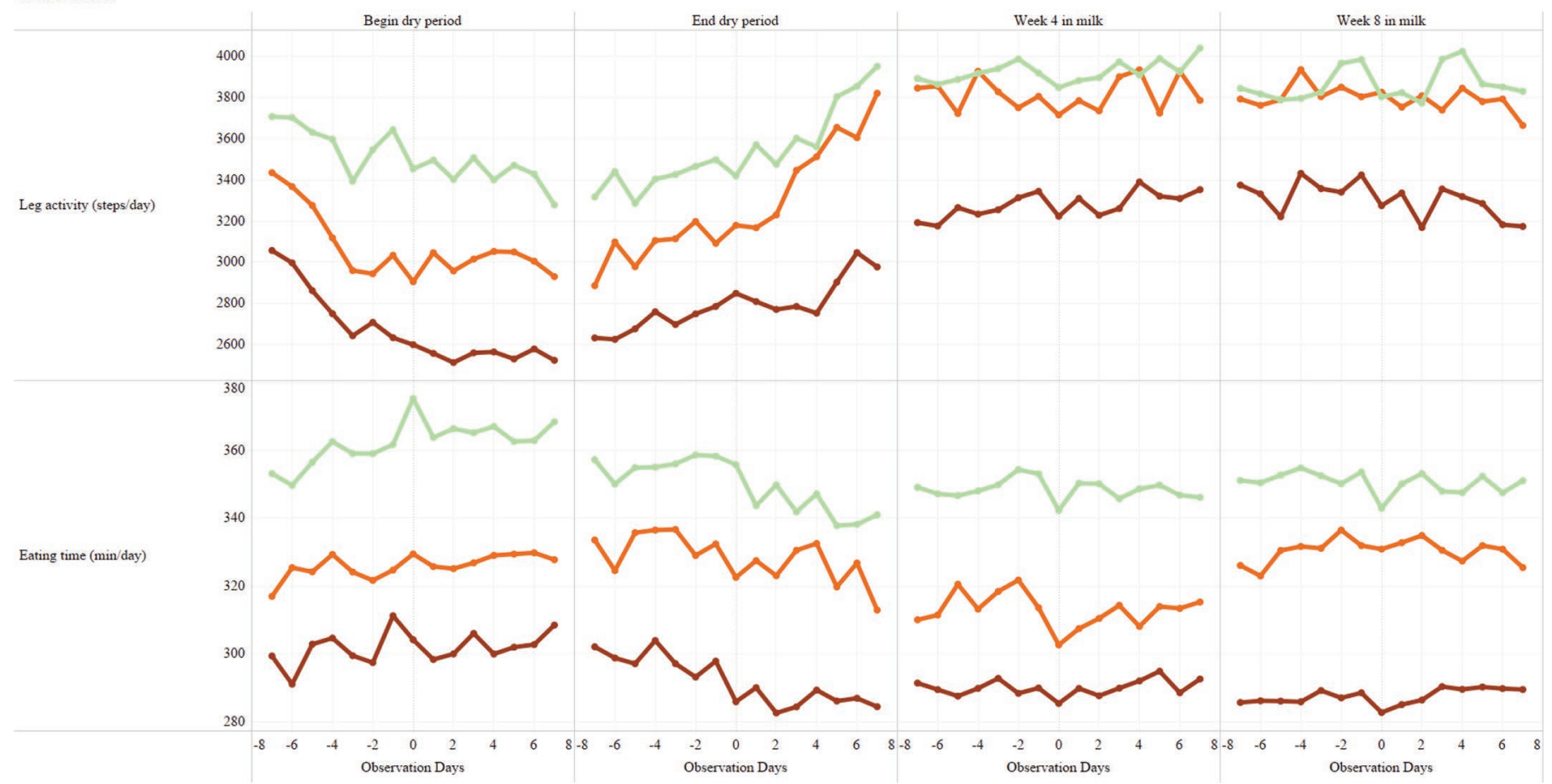

Figure 4. Descriptive values per scoring event (begin dry, end dry, 4 wk postpartum, 8 wk postpartum) for number of steps from the leg sensor and eating time from the neck sensor in 3 locomotion scoring groups (green $=$ nonlame; orange $=$ moderately lame; red $=$ severely lame) from $7 \mathrm{~d}$ before until $7 \mathrm{~d}$ after the day of scoring (d 0$)$. Number of multiparous cows with full sensor data per locomotion score group was as follows: begin dry period, total $\mathrm{n}=707$ (scores 1 and $2: \mathrm{n}=378$, score $3: \mathrm{n}=127$, scores 4 and $5: \mathrm{n}=205$ ); end dry period, total $\mathrm{n}=717$ (scores 1 and $2: \mathrm{n}=370$, score $3: \mathrm{n}=112$, scores 4 and $5: \mathrm{n}=235$ ); 4 wk in milk, total $\mathrm{n}=755$ (scores 1 and $2: \mathrm{n}=398$, score $3: \mathrm{n}=124$, scores 4 and $5: \mathrm{n}=233$ ); and $8 \mathrm{wk}$ in milk, total $\mathrm{n}=752$ ( 
percentage of cows with impaired locomotion in our study was unfortunately still as high as reported $18 \mathrm{yr}$ ago in a Dutch study (Somers et al., 2003). Comparable percentages of lame cows at the end of the dry period were seen by Daros et al. (2019). High locomotion scores have been associated with the weight of the calf in utero during the last part of gestation (Van Nuffel et al., 2016), udder size, and parity (Bölling and Pollott, 1998). A higher prevalence of sole ulcers has been reported in older cows (Holzhauer et al., 2008). Moreover, previous lameness could predispose cows for new cases of lameness (Randall et al., 2015). Lower feed intake is associated with an increase in lameness in high-producing cows (González et al., 2008; Grimm et al., 2019). In early lactation, a loss in BCS related to the negative energy balance in older cows could include a decrease in digital cushion thickness (Bicalho et al., 2009; McArt et al., 2013; Macrae et al., 2019). Our results support an association between BCS loss in early lactation and lameness at 4 wk postpartum (Chebel et al., 2018; Randall et al., 2018; Daros et al., 2019).
We observed most lameness postpartum in autumncalving cows and successively those that calved in summer, winter, and spring. Some of these autumn-calving cows had their dry periods during summer, whereas some were scored postpartum for locomotion in winter. Summer has been reported as a risk period for lameness (Sanders et al., 2009), but others found that lameness occurred more during winter (Cook, 2003; Espejo et al., 2006); therefore, the effect of season and climate is variable.

Sensor data from the leg sensor showed expected effects of lameness on walking and lying behavior, which is consistent with other studies (Ito et al., 2010; Westin et al., 2016). Others found a difference in leg activity between locomotion scores 1 and 2 (Thorup et al., 2015), indicating an underestimation in our study due to the combined analysis of locomotion scores 1 and 2 . Sensor data from the neck sensor showed that lameness was associated with important changes in feeding behavior (i.e., less eating time in the dry period and in early lactation). Reduced eating time in the dry

Table 4. Predicted mean values and 95\% CI for all sensor parameters based on reduced models with locomotion score group, pre- and postpartum, and first and second scores offered as explanatory variables to the full models and corrected for farm, calving season, and parity ${ }^{1}$

\begin{tabular}{|c|c|c|c|c|c|c|}
\hline Sensor parameter & \multicolumn{2}{|c|}{ Nonlame } & \multicolumn{2}{|c|}{ Moderately lame } & \multicolumn{2}{|c|}{ Severely lame } \\
\hline \multicolumn{7}{|l|}{ Walking } \\
\hline \multicolumn{7}{|l|}{ Steps (no./d) } \\
\hline Prepartum* & 3,128 & $3,013-3,247$ & $2,894^{\mathrm{a}}$ & $2,702-3,100$ & $2,910^{\mathrm{a}}$ & $2,753-3,076$ \\
\hline Postpartum & 3,722 & $3,572-3,879$ & 3,523 & $3,311-3,748$ & $3,116^{\mathrm{ab}}$ & $2,970-3,270$ \\
\hline \multicolumn{7}{|l|}{ Lying } \\
\hline \multicolumn{7}{|l|}{ Lying bouts (no./d) } \\
\hline Prepartum* & 5.85 & $5.69-6.00$ & 5.98 & $5.72-6.25$ & 5.95 & $5.72-6.17$ \\
\hline Postpartum & 6.64 & $6.47-6.81$ & 6.64 & $6.40-6.89$ & $6.35^{\mathrm{ab}}$ & $6.16-6.55$ \\
\hline Lying bout length (min/bout) & 111 & $108-114$ & 112 & $108-116$ & $119^{\mathrm{ab}}$ & $115-123$ \\
\hline \multicolumn{7}{|l|}{ Feeding } \\
\hline \multicolumn{7}{|l|}{ Eating time $(\mathrm{min} / \mathrm{d})$} \\
\hline Prepartum* & 362 & $355-370$ & $342^{\mathrm{a}}$ & $331-352$ & $325^{\mathrm{ab}}$ & $316-334$ \\
\hline Rumination time $(\min / \mathrm{d})$ & 545 & $538-552$ & 546 & $536-555$ & 539 & $531-548$ \\
\hline Rumination bouts (no./d) & 14.8 & $14.6-15.0$ & 15.0 & $14.6-15.3$ & 15.0 & $14.7-15.3$ \\
\hline \multicolumn{7}{|c|}{ Rumination bout length (min/bout) } \\
\hline Prepartum* & 37.7 & $36.9-38.4$ & $36.6^{\mathrm{c}}$ & $35.4-37.8$ & $36.3^{\mathrm{a}}$ & $35.3-37.3$ \\
\hline Postpartum & 36.7 & $35.9-37.6$ & 37.0 & $35.9-38.1$ & 36.4 & $35.5-37.3$ \\
\hline
\end{tabular}

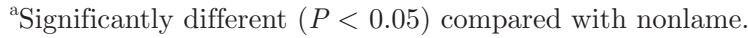

${ }^{\mathrm{b}}$ Significantly different $(P<0.05)$ compared with moderately lame.

${ }^{\mathrm{c}}$ Trend $(P<0.1)$ compared with nonlame.

${ }^{\mathrm{d}}$ Trend $(P<0.1)$ compared with moderately lame.

${ }^{1}$ For the number of stand-ups, daily rumination time, and the number of rumination bouts, locomotion scores were forced in the reduced models.

*Significant effect $(P<0.05)$ of difference between pre- and postpartum scores or first and second scores. 
period has been related to a higher risk for metritis, ketosis, and other transition diseases in early lactation and a longer interval between calving and first service (Schirmann et al., 2016; Hut et al., 2019; Daros et al., 2020). Postpartum, a negative energy balance has a negative effect on reproduction and results in decreased milk production (Esposito et al., 2014; Llonch et al., 2018). These studies indicate the importance of eating time in the dry and transition periods and the related feed intake. In our study, only severely lame dry cows showed shorter rumination bout length, whereas in lactation no association was found between locomotion score and rumination parameters, which is consistent with Thorup et al. (2016).

A

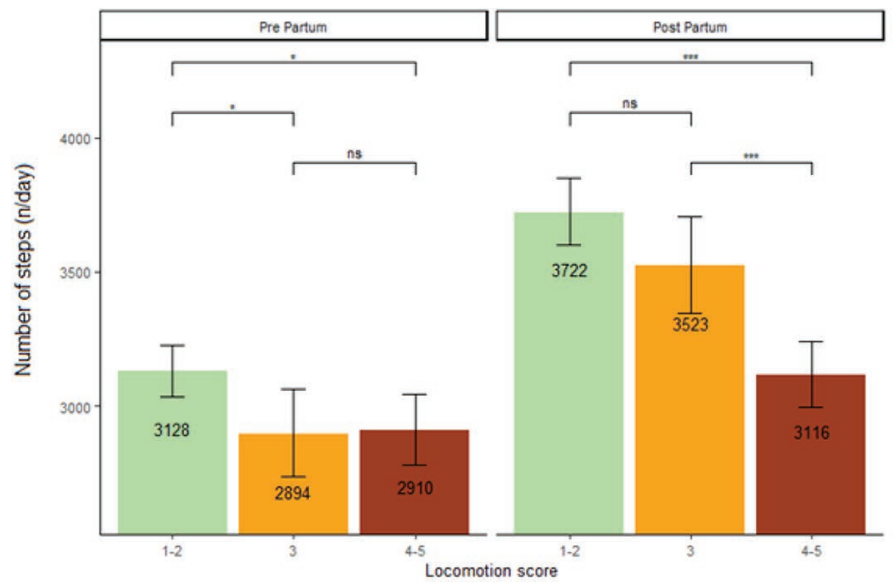

C

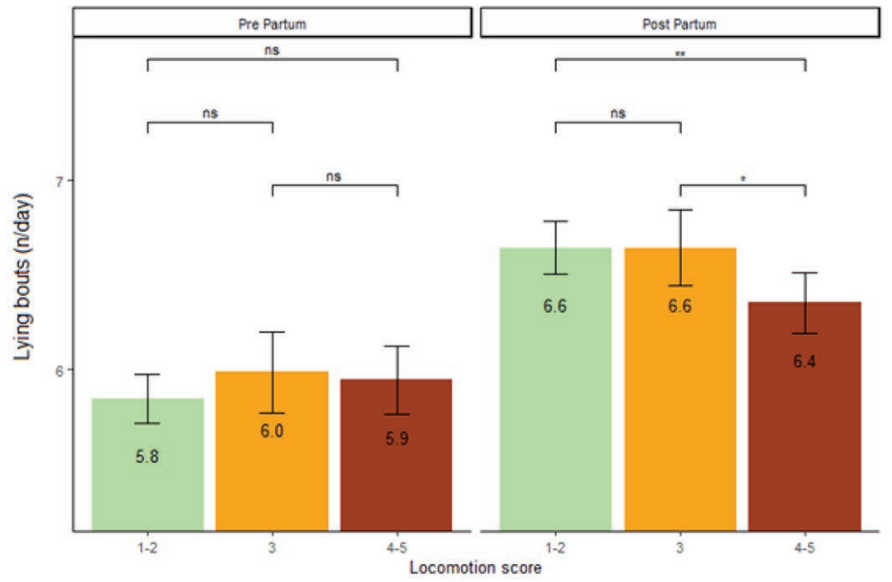

Behavioral differences as measured by sensor technology have been reported between cows in the dry period and those in early lactation and between primiparous and multiparous cows (Neave et al., 2017; Hut et al., 2019). In our study, lactating cows showed a higher number of steps, more lying bouts, less eating time with more eating bouts, and shorter rumination bout length compared with dry cows. We included calving season in our sensor data models because the 1.5-yr study period contained 6 mo of winter, 4 mo of spring, 3 mo of summer, and 5 mo of autumn. If we excluded calving season, these effects were picked up by a more evident contrast between dry and lactating animals (results not shown). We could not include effects of stocking densities in the

B

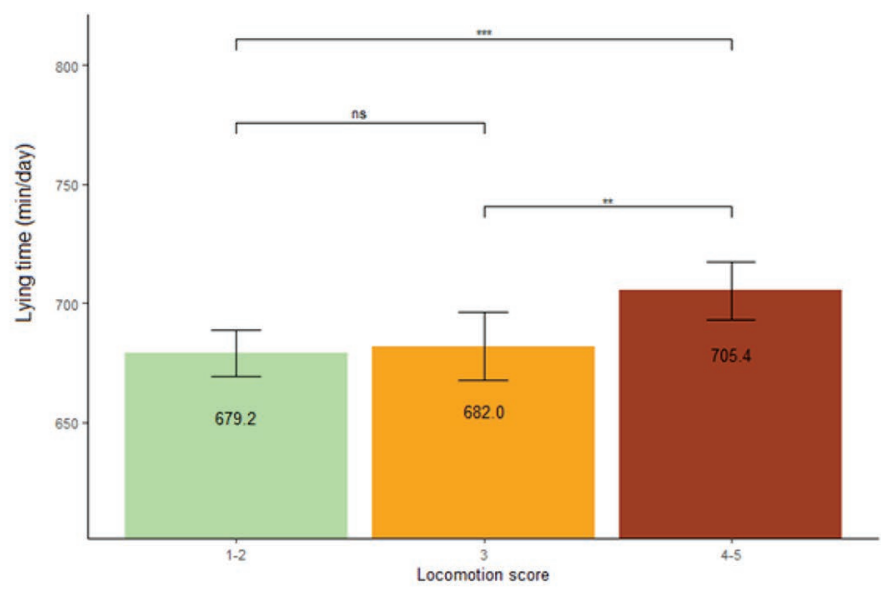

$\mathrm{D}$

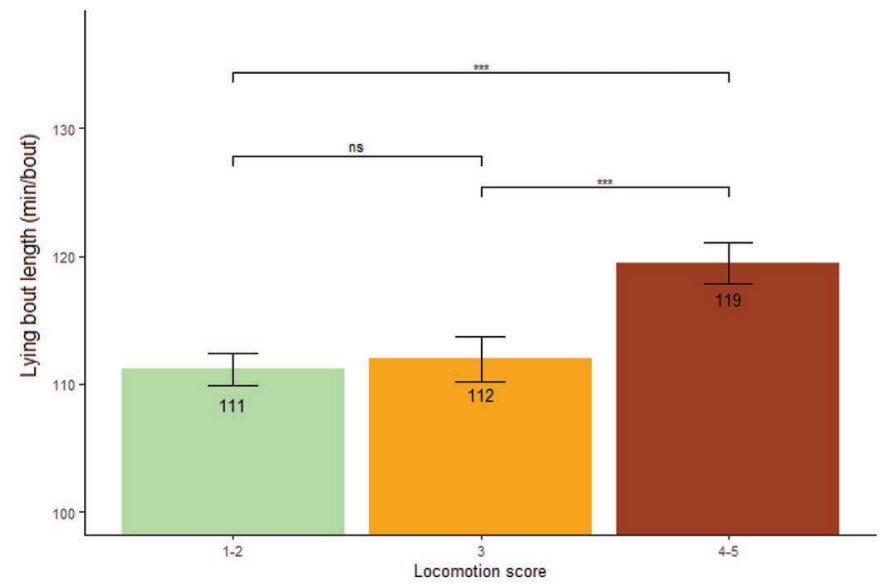

Figure 5. Results of the final models from the leg sensor per locomotion score group (green = nonlame; orange = moderately lame; red $=$ severely lame) with $95 \%$ CI (error bars) and level of significance. ${ }^{*} P<0.05,{ }^{* *} P<0.01,{ }^{* * *} P<0.001$. Difference in mean daily number of steps (A), lying time (B), lying bouts (C), and lying bout length (D). 
dry period and early lactation, which may vary within farm by season, because these data were not collected. These farms do not have a policy to use overstocking, but the exact stocking densities per scoring moment were not recorded despite the known effect of stocking density on daily behavior of dairy cattle (Huzzey et al., 2006; Jensen and Proudfoot, 2017).

In this study, foot trimming data or lameness diagnosis were not taken into account due to practical constraints. To understand underlying causes of the incidence of high locomotion scores in transition cows, a weekly scoring interval followed by lameness diagnosis for scores $\geq 3$ should be implemented at least (Randall et al., 2015). Such scheme would allow a proper estimation of the incidence of diagnosed new cases of lameness that could be combined with the complete time budget of dairy cows as precisely measured with sensors. How- ever, our study adds impaired locomotion as an explanation for reduced eating time in the dry period, with potential long-lasting effects on postpartum metabolic status and productive and reproductive success.

\section{CONCLUSIONS}

This study showed a high prevalence of locomotion scores 3 to 5 and an increase in locomotion scores 3 to 5 from the dry period up to 8 wk in lactation. Although the time budget of dairy cows differed between the dry and lactating periods using locomotion scores 1 and 2 (nonlame) as a baseline, more importantly, sensor data showed that daily eating time was reduced $38 \mathrm{~min}$ for locomotion scores 4 and 5 (severely lame) and $20 \mathrm{~min}$ for locomotion score 3 (moderately lame). This study shows that loss of BCS in early lactation is associated

\section{A}

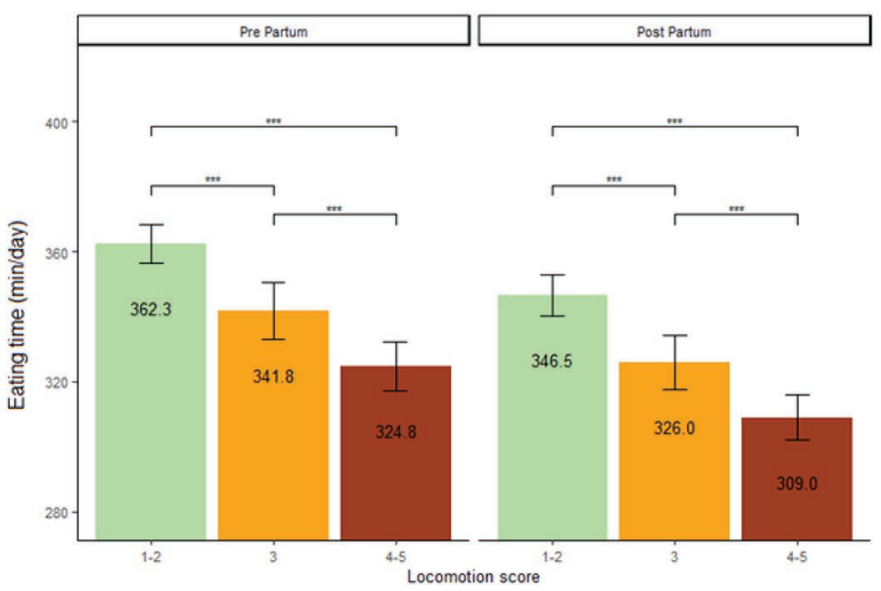

C

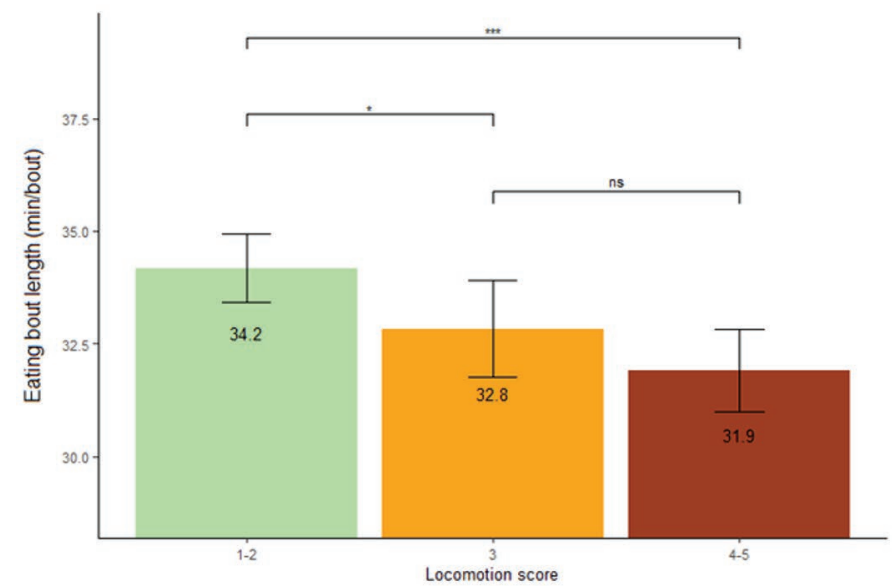

B

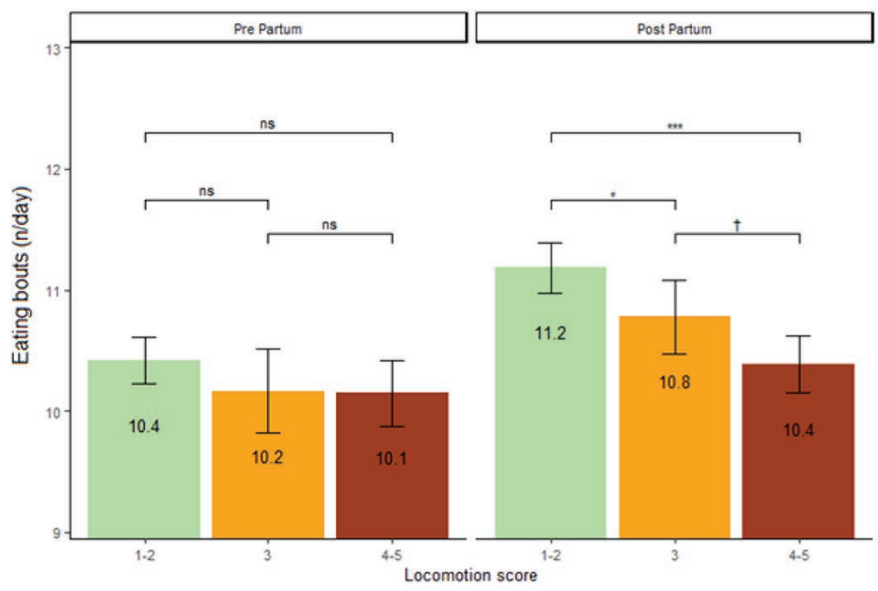

D

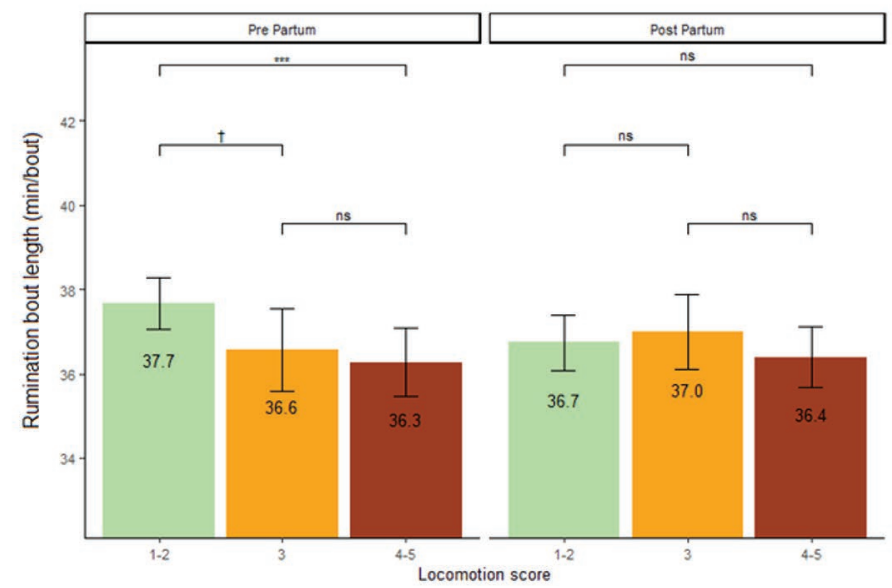

Figure 6. Results of the final models from the neck sensor per locomotion score group (green = nonlame; orange $=$ moderately lame; red $=$ severely lame) with $95 \%$ CI (error bars) and level of significance. ${ }^{*} P<0.05, * * * P<0.001, \dagger P<0.1$. Difference in mean daily eating time $($ A) number of eating bouts $(\mathrm{B})$, eating bout length $(\mathrm{C})$, and rumination bout length $(\mathrm{D})$. 
with increased odds for lameness in wk 4 postpartum. Lameness is associated with less eating time in the dry period as well as in early lactation.

\section{ACKNOWLEDGMENTS}

The authors thank all the farmers for their cooperation and Nedap Livestock Management (Groenlo, the Netherlands), especially Arnold Harbers, for providing the sensor data. We also thank Klaas Frankena from Wageningen University and Research (Wageningen, the Netherlands) and Jan van den Broek from Utrecht University (Utrecht, the Netherlands) for valuable feedback. Furthermore, we thank Linda McPhee (Linda McPhee consulting, Suffolk, UK) for editing the language of the manuscript. $\mathrm{PH}$ and $\mathrm{MB}$ collected the data, and $\mathrm{PH}$ wrote the paper. Analysis was carried out by $\mathrm{MH}$ and $\mathrm{PH}$, supervised by MN. The study was designed by PH, MH, FE, JH, GH, ES, and MN. All authors read and approved the final manuscript. $\mathrm{JH}$ is co-owner of Vetvice BV (Bergen op Zoom, the Netherlands). All authors declare that they have no conflict of interest related to the study discussed in this manuscript.

\section{REFERENCES}

Alsaaod, M., S. Huber, G. Beer, P. Kohler, G. Schupbach-Regula, and A. Steiner. 2017. Locomotion characteristics of dairy cows walking on pasture and the effect of artificial flooring systems on locomotion comfort. J. Dairy Sci. 100:8330-8337. https://doi.org/ $10.3168 /$ jds.2017-12760.

Amory, J. R., Z. E. Barker, J. L. Wright, S. A. Mason, R. W. Blowey, and L. E. Green. 2008. Associations between sole ulcer, white line disease and digital dermatitis and the milk yield of 1824 dairy cows on 30 dairy cow farms in England and Wales from February 2003-November 2004. Prev. Vet. Med. 83:381-391. https://doi .org/10.1016/j.prevetmed.2007.09.007.

Bache, S. M., and H. Wickham. 2014. Magrittr: A forward-pipe operator for R. R package version 1.5. https://CRAND.R-project.org/ package $=$ magrittr.

Barker, Z. E., K. A. Leach, H. R. Whay, N. J. Bell, and D. C. Main. 2010. Assessment of lameness prevalence and associated risk factors in dairy herds in England and Wales. J. Dairy Sci. 93:932-941. https://doi.org/10.3168/jds.2009-2309.

Bates, D., M. Mächler, B. Bolker, and S. Walker. 2015. Fitting linear mixed-effects models using lme4. J. Stat. Softw. 67:1-48. https:// doi.org/10.18637/jss.v067.i01.

Bicalho, R. C., V. S. Machado, and L. S. Caixeta. 2009. Lameness in dairy cattle: A debilitating disease or a disease of debilitated cattle? A cross-sectional study of lameness prevalence and thickness of the digital cushion. J. Dairy Sci. 92:3175-3184. https://doi .org/10.3168/jds.2008-1827.

Blackie, N., E. C. L. Bleach, J. R. Amory, and J. R. Scaife. 2013. Associations between locomotion score and kinematic measures in dairy cows with varying hoof lesion types. J. Dairy Sci. 96:35643572. https://doi.org/10.3168/jds.2012-5597.

Bölling, D., and G. E. Pollott. 1998. Locomotion, lameness, hoof and leg traits in cattle I: Phenotypic influences and relationships. Livest. Prod. Sci. 54:193-203. https://doi.org/10.1016/S0301 -6226(97)00166-8.

Bruijnis, M. R. N., B. Beerda, H. Hogeveen, and E. N. Stassen. 2012. Assessing the welfare impact of foot disorders in dairy cattle by a modeling approach. Animal 6:962-970. https://doi.org/10.1017/ S1751731111002606.

Channon, A. J., A. M. Walker, T. Pfau, I. M. Sheldon, and A. M. Wilson. 2009. Variability of Manson and Leaver locomotion scores assigned to dairy cows by different observers. Vet. Rec. 164:388-392. https://doi.org/10.1136/vr.164.13.388.

Chapinal, N., A. M. de Passille, D. M. Weary, M. A. von Keyserlingk, and J. Rushen. 2009. Using gait score, walking speed, and lying behavior to detect hoof lesions in dairy cows. J. Dairy Sci. 92:4365-4374. https://doi.org/10.3168/jds.2009-2115.

Chebel, R. C., L. G. D. Mendonça, and P. S. Baruselli. 2018. Association between body condition score change during the dry period and postpartum health and performance. J. Dairy Sci. 101:45954614. https://doi.org/10.3168/jds.2017-13732.

Cook, N. B. 2003. Prevalence of lameness among dairy cattle in Wisconsin as a function of housing type and stall surface. J. Am. Vet. Med. Assoc. 223:1324-1328. https://doi.org/10.2460/javma.2003 .223 .1324 .

Cook, N. B., T. B. Bennett, and K. V. Nordlund. 2004. Effect of free stall surface on daily activity patterns in dairy cows with relevance to lameness prevalence. J. Dairy Sci. 87:2912-2922. https://doi .org/10.3168/jds.S0022-0302(04)73422-0.

Daros, R. R., H. K. Eriksson, D. M. Weary, and M. A. G. von Keyserlingk. 2019. Lameness during the dry period: Epidemiology and associated factors. J. Dairy Sci. 102:11414-11427. https://doi.org/ 10.3168/jds.2019-16741.

Daros, R. R., H. K. Eriksson, D. M. Weary, and M. A. G. von Keyserlingk. 2020. The relationship between transition period diseases and lameness, feeding time, and body condition during the dry period. J. Dairy Sci. 103:649-665. https://doi.org/10.3168/jds.2019 $-16975$.

Dohoo, I. R., W. Martin, and H. Stryhn. 2003. Veterinary Epidemiologic Research. AVC Inc., University of Prince Edward Island, Charlottetown, PEI, Canada.

Dowle, M., and A. Srinivasan. 2019. Extension of 'data.frame.' R package version 1.12.2. https://CRAN.R-project.org/package=data table.

Drackley, J. K. 1999. Biology of dairy cows during the transition period: The final frontier? J. Dairy Sci. 82:2259-2273. https://doi .org/10.3168/jds.S0022-0302(99)75474-3.

Dyer, R. M., N. K. Neerchal, U. Tasch, Y. Wu, P. Dyer, and P. G. Rajkondawar. 2007. Objective determination of claw pain and its relationship to limb locomotion score in dairy cattle. J. Dairy Sci. 90:4592-4602. https://doi.org/10.3168/jds.2007-0006.

Enting, H., D. Kooij, A. A. Dijkhuizen, R. B. M. Huirne, and E. N Noordhuizen-Stassen. 1997. Economic losses due to clinical lameness in dairy cattle. Livest. Prod. Sci. 49:259-267. https://doi.org/ 10.1016/S0301-6226(97)00051-1.

Espejo, L. A., M. I. Endres, and J. A. Salfer. 2006. Prevalence of lameness in high-producing Holstein cows housed in freestall barns in Minnesota. J. Dairy Sci. 89:3052-3058. https://doi.org/10.3168/ jds.S0022-0302(06)72579-6.

Esposito, G., P. C. Irons, E. C. Webb, and A. Chapwanya. 2014. Interactions between negative energy balance, metabolic diseases, uterine health and immune response in transition dairy cows. Anim. Reprod. Sci. 144:60-71. https://doi.org/10.1016/j.anireprosci.2013 .11 .007 .

Ferguson, J. D., D. T. Galligan, and N. Thomsen. 1994. Principal descriptors of body condition score in Holstein cows. J. Dairy Sci. 77:2695-2703. https://doi.org/10.3168/jds.S0022-0302(94)77212 $-\mathrm{X}$.

Fox, J., and S. Weisberg. 2011. An R Companion to Applied Regression. 2nd ed. Sage, Thousand Oaks, CA.

Fox, J., and S. Weisberg. 2018. Visualizing fit and lack of fit in complex regression models with predictor. J. Stat. Softw. 8:1-27.

Frankena, K., J. G. C. J. Somers, W. G. P. Schouten, J. V. Van Stek, J. H. M. Metz, E. N. Stassen, and E. A. M. Graat. 2009. The effect of digital lesions and floor type on locomotion score in Dutch dairy cows. Prev. Vet. Med. 88:150-157. https://doi.org/10.1016/ j.prevetmed.2008.08.004. 
Gomez, A., and N. B. Cook. 2010. Time budgets of lactating dairy cattle in commercial freestall herds. J. Dairy Sci. 93:5772-5781. https://doi.org/10.3168/jds.2010-3436.

González, L. A., B. J. Tolkamp, M. P. Coffey, A. Ferret, and I. Kyriazakis. 2008. Changes in feeding behavior as possible indicators for the automatic monitoring of health disorders in dairy cows. J. Dairy Sci. 91:1017-1028. https://doi.org/10.3168/jds.2007-0530.

Graves, S., H. P. Piepho, L. Selzer. 2019. multcompView. R package version 0.1.8. https://cran.r-project.org/web/packages/ multcompView/index.html.

Green, L. E., V. J. Hedges, Y. H. Schukken, R. W. Blowey, and A. J. Packington. 2002. The impact of clinical lameness on the milk yield of dairy cows. J. Dairy Sci. 85:2250-2256. https://doi.org/10 $.3168 /$ jds.S0022-0302(02)74304-X.

Grimm, K., B. Haidn, M. Erhard, M. Tremblay, and D. Döpfer. 2019. New insights into the association between lameness, behavior, and performance in Simmental cows. J. Dairy Sci. 102:2453-2468. https://doi.org/10.3168/jds.2018-15035.

Hernandez, J., J. K. Shearer, and D. W. Webb. 2002. Effect of lameness on milk yield in dairy cows. J. Am. Vet. Med. Assoc. 220:640644. https://doi.org/10.2460/javma.2002.220.640.

Holzhauer, M., C. Hardenberg, and C. J. Bartels. 2008. Herd and cowlevel prevalence of sole ulcers in The Netherlands and associatedrisk factors. Prev. Vet. Med. 85:125-135. https://doi.org/10.1016/ j.prevetmed.2008.01.004.

Holzhauer, M., C. Hardenberg, C. J. Bartels, and K. Frankena. 2006. Herd- and cow-level prevalence of digital dermatitis in the Netherlands and associated risk factors. J. Dairy Sci. 89:580-588. https:/ /doi.org/10.3168/jds.S0022-0302(06)72121-X.

Hut, P. R., A. Mulder, J. van den Broek, J. H. J. L. Hulsen, G. A. Hooijer, E. N. Stassen, F. J. C. M. van Eerdenburg, and M. Nielen. 2019. Sensor based eating time variables of dairy cows in the transition period related to the time to first service. Prev. Vet. Med. 169:104694. https://doi.org/10.1016/j.prevetmed.2019.104694.

Huzzey, J. M., T. J. DeVries, P. Valois, and M. A. G. von Keyserlingk. 2006. Stocking density and feed barrier design affect the feeding and social behavior of dairy cattle. J. Dairy Sci. 89:126-133. https: //doi.org/10.3168/jds.S0022-0302(06)72075-6.

Ito, K., M. A. von Keyserlingk, S. J. Leblanc, and D. M. Weary. 2010. Lying behavior as an indicator of lameness in dairy cows. J. Dairy Sci. 93:3553-3560. https://doi.org/10.3168/jds.2009-2951.

Jensen, M. B., and K. L. Proudfoot. 2017. Effect of group size and health status on behaviour and feed intake of multiparous dairy cows in early lactation. J. Dairy Sci. 100:9759-9768. https://doi .org/10.3168/jds.2017-13035.

Kassambara, A. 2018. Ggpubr: 'ggplot2' based publication ready plots. $\mathrm{R}$ package version 0.1.8. https://CRAN.R-project.org/package= ggpubr.

King, M. T. M., S. J. LeBlanc, E. A. Pajor, T. C. Wright, and T. J. DeVries. 2018. Behavior and productivity of cows milked in automated systems before diagnosis of health disorders in early lactation. J. Dairy Sci. 101:4343-4356. https://doi.org/10.3168/ jds.2017-13686.

Kok, A., R. J. van Hoeij, B. J. Tolkamp, M. J. Haskell, A. T. M. van Knegsel, I. J. M. de Boer, and E. A. M. Bokkers. 2017. Behavioural adaptation to a short or no dry period with associated management in dairy cows. Appl. Anim. Behav. Sci. 186:7-15. https://doi .org/10.1016/j.applanim.2016.10.017.

Lenth, R. V. 2016. Least squares means: The R package lsmeans. J. Stat. Softw. 69:1-33. https://doi.org/10.18637/jss.v069.i01.

Llonch, P., E. Mainau, I. R. Ipharraguerre, F. Bargo, G. Tedó, M. Blanch, and X. Manteca. 2018. Chicken or the egg: The reciprocal association between feeding behavior and animal welfare and their impact on productivity in dairy cows. Front. Vet. Sci. 5:305. https: //doi.org/10.3389/fvets.2018.00305.

Macrae, A. I., E. Burrough, J. Forrest, A. Corbishley, G. Russell, and D. J. Shaw. 2019. Risk factors associated with excessive negative energy balance in commercial United Kingdom dairy herds. Vet. J. 250:15-23. https://doi.org/10.1016/j.tvjl.2019.06.001.

McArt, J. A. A., D. V. Nydam, and G. R. Oetzel. 2013. Dry period and parturient predictors of early lactation hyperketonemia in dairy cattle. J. Dairy Sci. 96:198-209. https://doi.org/10.3168/ jds. 2012-5681.

Melendez, P., J. Bartolome, L. F. Archbald, and A. Donovan. 2003. The association between lameness, ovarian cysts and fertility in lactating dairy cows. Theriogenology 59:927-937. https://doi.org/ 10.1016/S0093-691X(02)01152-4.

Neave, H. W., J. Lomb, M. A. G. von Keyserlingk, A. Behnam-Shabahang, and D. M. Weary. 2017. Parity differences in the behavior of transition dairy cows. J. Dairy Sci. 100:548-561. https://doi.org/ 10.3168/jds.2016-10987.

Nielsen, P. P., I. Fontana, K. H. Sloth, M. Guarino, and H. Blokhuis. 2018. Technical note: Validation and comparison of 2 commercially available activity loggers. J. Dairy Sci. 101:5449-5453. https://doi .org/10.3168/jds.2017-13784.

O'Callaghan, K. A., P. J. Cripps, D. Y. Downham, and R. D. Murray. 2003. Subjective and objective assessment of pain and discomfort due to lameness in dairy cattle. Anim. Welf. 12:605-610.

R Core Team. 2019. R: A language and environment for statistical computing. R Foundation for Statistical Computing, Vienna, Austria. https://www.R-project.org/.

Randall, L. V., M. J. Green, M. G. Chagunda, C. Mason, S. C. Archer, L. E. Green, and J. N. Huxley. 2015. Low body condition predisposes cattle to lameness: An 8-year study of one dairy herd. J. Dairy Sci. 98:3766-3777. https://doi.org/10.3168/jds.2014-8863.

Randall, L. V., M. J. Green, L. E. Green, M. G. G. Chagunda, C. Mason, S. C. Archer, and J. N. Huxley. 2018. The contribution of previous lameness events and body condition score to the occurrence of lameness in dairy herds: A study of 2 herds. J. Dairy Sci. 101:1311-1324. https://doi.org/10.3168/jds.2017-13439.

Randall, L. V., H. J. Thomas, J. G. Remnant, N. J. Bollard, and J. N. Huxley. 2019. Lameness prevalence in a random sample of UK dairy herds. Vet. Rec. 184:350. https://doi.org/10.1136/vr.105047.

Sanders, A. H., J. K. Shearer, and A. De Vries. 2009. Seasonal incidence of lameness and risk factors associated with thin soles, white line disease, ulcers, and sole punctures in dairy cattle. J. Dairy Sci. 92:3165-3174. https://doi.org/10.3168/jds.2008-1799.

Schirmann, K., D. M. Weary, W. Heuwieser, N. Chapinal, R. L. A. Cerri, and M. A. G. Von Keyserlingk. 2016. Rumination and feeding behaviors differ between healthy and sick dairy cows during the transition period. J. Dairy Sci. 99:9917-9924. https://doi.org/ 10.3168/jds.2015-10548.

Solano, L., H. W. Barkema, E. A. Pajor, S. Mason, S. J. LeBlanc, C. G. R. Nash, D. B. Haley, D. Pellerin, J. Rushen, A. M. de Passillé, E. Vasseur, and K. Orsel. 2016. Associations between lying behavior and lameness in Canadian Holstein-Friesian cows housed in freestall barns. J. Dairy Sci. 99:2086-2101. https://doi.org/10 $.3168 /$ jds.2015-10336.

Solano, L., H. W. Barkema, E. A. Pajor, S. Mason, S. J. LeBlanc, J. C. Zaffino Heyerhoff, C. G. Nash, D. B. Haley, E. Vasseur, D. Pellerin, J. Rushen, A. M. de Passille, and K. Orsel. 2015. Prevalence of lameness and associated risk factors in Canadian Holstein-Friesian cows housed in freestall barns. J. Dairy Sci. 98:6978-6991. https:/ /doi.org/10.3168/jds.2015-9652.

Somers, J. G., K. Frankena, E. N. Noordhuizen-Stassen, and J. H. Metz. 2003. Prevalence of claw disorders in Dutch dairy cows exposed to several floor systems. J. Dairy Sci. 86:2082-2093. https:/ /doi.org/10.3168/jds.S0022-0302(03)73797-7.

Sprecher, D. J., D. E. Hostetler, and J. B. Kaneene. 1997. A lameness scoring system that uses posture and gait to predict dairy cattle reproductive performance. Theriogenology 47:1179-1187. https:// doi.org/10.1016/S0093-691X(97)00098-8.

Steensels, M., E. Maltz, C. Bahr, D. Berckmans, A. Antler, and I. Halachmi. 2017. Towards practical application of sensors for monitoring animal health: The effect of post-calving health problems on rumination duration, activity and milk yield. J. Dairy Res. 84:132-138. https://doi.org/10.1017/S0022029917000176.

Telezhenko, E., M. Magnusson, and C. Bergsten. 2017. Gait of dairy cows on floors with different slipperiness. J. Dairy Sci. 100:64946503. https://doi.org/10.3168/jds.2016-12208.

Thorup, V. M., L. Munksgaard, P. E. Robert, H. W. Erhard, P. T. Thomsen, and N. C. Friggens. 2015. Lameness detection via leg- 
mounted accelerometers on dairy cows on four commercial farms. Animal 9:1704-1712. https://doi.org/10.1017/S1751731115000890.

Thorup, V. M., B. L. Nielsen, P. E. Robert, S. Giger-Reverdin, J. Konka, C. Michie, and N. C. Friggens. 2016. Lameness affects cow feeding but not rumination behavior as characterized from sensor data. Front. Vet. Sci. 3:37. https://doi.org/10.3389/fvets 2016.00037.

van der Tol, P. P. J., J. H. M. Metz, E. N. Noordhuizen-Stassen, W. Back, C. R. Braam, and W. A. Weijs. 2005. Frictional forces required for unrestrained locomotion in dairy cattle. J. Dairy Sci. 88:615-624. https://doi.org/10.3168/jds.S0022-0302(05)72725-9.

Van Erp-Van der Kooij, E., M. Van de Brug, and J. B. Roelofs. 2016. Validation of Nedap Smarttag leg and neck to assess behavioural activity level in dairy cattle. Pages $321-326$ in Proc. Precision Dairy Farming 2016. Wageningen Academic Publishers, Leeuwarden, the Netherlands.

Van Nuffel, A., T. Van De Gucht, W. Saeys, B. Sonck, G. Opsomer, J. Vangeyte, K. C. Mertens, B. De Ketelaere, and S. Van Weyenberg. 2016. Environmental and cow-related factors affect cow locomotion and can cause misclassification in lameness detection systems. Animal 10:1533-1541. https://doi.org/10.1017/S175173111500244X.

Weigele, H. C., L. Gygax, A. Steiner, B. Wechsler, and J. B. Burla. 2018. Moderate lameness leads to marked behavioral changes in dairy cows. J. Dairy Sci. 101:2370-2382. https://doi.org/10.3168/ jds.2017-13120.
Westin, R., A. Vaughan, A. M. de Passillé, T. J. DeVries, E. A. Pajor, D. Pellerin, J. M. Siegford, A. Witaifi, E. Vasseur, and J. Rushen. 2016. Cow- and farm-level risk factors for lameness on dairy farms with automated milking systems. J. Dairy Sci. 99:3732-3743. https://doi.org/10.3168/jds.2015-10414.

Wickham, H. 2016. Ggplot2: Elegant Graphics for Data Analysis. Springer-Verlag, New York, NY.

Wickham, H., R. Francois, L. Henry, and K. Müller. 2018. Dplyr: A grammar of data manipulation. $\mathrm{R}$ package version 0.7.5. https:// CRAN.R-project.org/package $=$ dplyr.

Wickham, H., and L. Henry. 2019. Tidyr: Easily tidy data with 'spread()' and 'gather()' functions. R package version 0.8.3. https: //CRAN.R-project.org/package=tidyr.

\section{ORCIDS}

P. R. Hut (ํ) https://orcid.org/0000-0003-0874-6002

M. M. Hostens @ https://orcid.org/0000-0001-5376-976X

M. J. Beijaard ๑ https://orcid.org/0000-0002-5994-9662

F. J. C. M. van Eerdenburg ( https://orcid.org/0000-0002-6024-6905

J. H. J. L. Hulsen (๑) https://orcid.org/0000-0002-6851-4433

G. A. Hooijer @ https://orcid.org/0000-0003-2084-9469

M. Nielen (® https://orcid.org/0000-0001-6909-877X 


\section{APPENDIX}

Table A1. Variables used in the association models on lameness in wk 4 and 8 postpartum in the univariable analysis and variables remaining in the final reduced models ${ }^{1}$

\begin{tabular}{|c|c|c|c|}
\hline Model & Variable $^{2}$ & Univariable analysis & Final reduced model \\
\hline \multirow[t]{8}{*}{ Wk 4} & Parity & $x$ & $x$ \\
\hline & BCS early dry & $x$ & \\
\hline & BCS end dry & $x$ & \\
\hline & BCS wk 4 & $x$ & \\
\hline & BCS change dry & $\times$ & \\
\hline & BCS change transition & $x$ & $\times$ \\
\hline & Dry period length & $x$ & \\
\hline & Calving season & $\times$ & $x$ \\
\hline \multirow[t]{10}{*}{ Wk 8} & Parity & $\times$ & $x$ \\
\hline & BCS early dry & $\times$ & \\
\hline & BCS end dry & $x$ & \\
\hline & BCS wk 4 & $x$ & \\
\hline & BCS wk 8 & $\times$ & \\
\hline & BCS change dry & $\times$ & \\
\hline & BCS change transition & $\times$ & \\
\hline & BCS change postpartum & $x$ & \\
\hline & Dry period length & $x$ & \\
\hline & Calving season & $\times$ & $x$ \\
\hline
\end{tabular}

${ }^{1}$ Data were based on 784 multiparous cows in 8 commercial dairy farms in the Netherlands. Cows were scored 4 times: in the early dry period, at the end of the dry period, at 4 wk postpartum, and at 8 wk postpartum. ${ }^{2}$ BCS change dry = BCS end - BCS early. BCS change transition = BCS wk $4-$ BCS end dry. Dry period length $=$ number of days between first score and calving date. Calving season = summer, autumn, winter, and spring.

Table A2. Variables that remained in the 10 final reduced sensor data models based on 784 multiparous cows in 8 commercial dairy farms in the Netherlands ${ }^{1}$

\begin{tabular}{|c|c|c|c|c|c|c|c|c|c|c|}
\hline \multirow[b]{2}{*}{ Variable $^{2}$} & \multicolumn{4}{|c|}{ Leg sensor } & \multicolumn{6}{|c|}{ Neck sensor } \\
\hline & $\begin{array}{l}\text { No. of } \\
\text { steps }\end{array}$ & $\begin{array}{l}\text { Lying } \\
\text { time }\end{array}$ & $\begin{array}{l}\text { Lying } \\
\text { bouts }\end{array}$ & $\begin{array}{c}\text { Lying } \\
\text { bout } \\
\text { length }\end{array}$ & $\begin{array}{l}\text { Eating } \\
\text { time }\end{array}$ & $\begin{array}{l}\text { Eating } \\
\text { bouts }\end{array}$ & $\begin{array}{c}\text { Eating } \\
\text { bout } \\
\text { length }\end{array}$ & $\begin{array}{c}\text { Rumination } \\
\text { time }\end{array}$ & $\begin{array}{c}\text { Rumination } \\
\text { bouts }\end{array}$ & $\begin{array}{l}\text { Rumination } \\
\text { bout length }\end{array}$ \\
\hline $\mathrm{LS}$ & $\times$ & $\times$ & $x$ & $\times$ & $x$ & $x$ & $\times$ & $\times$ & $\times$ & $x$ \\
\hline $\mathrm{ObP}$ & $\times$ & $\times$ & $\times$ & $\times$ & $\times$ & $x$ & $\times$ & $\times$ & $\times$ & $x$ \\
\hline ObM & $\times$ & $\times$ & $\times$ & $\times$ & $\times$ & $\times$ & $\times$ & $\times$ & $\times$ & $\times$ \\
\hline $\mathrm{CS}$ & $\times$ & $\times$ & $\times$ & $\times$ & & $\times$ & $\times$ & $\times$ & & $\times$ \\
\hline ObP:ObM & $\times$ & & $x$ & $\times$ & $\times$ & $\times$ & $\times$ & $\times$ & $\times$ & \\
\hline ObP:LS & $\times$ & & $\times$ & $\times$ & & $\times$ & & & & $\times$ \\
\hline ObM:LS & & & & $\times$ & $\times$ & & & & & \\
\hline ObP:LS:ObM & & & & $\times$ & & & & & & \\
\hline Farm & $\times$ & $\times$ & $x$ & $\times$ & $\times$ & $\times$ & $\times$ & $\times$ & $\times$ & $\times$ \\
\hline Parity & $\times$ & $\times$ & $x$ & $\times$ & $\times$ & $\times$ & $\times$ & $\times$ & & $\times$ \\
\hline Cow & $\times$ & $\times$ & $\times$ & $\times$ & $\times$ & $\times$ & $\times$ & $\times$ & $\times$ & $\times$ \\
\hline
\end{tabular}

${ }^{1}$ Cows were scored 4 times: in the early dry period, at the end of the dry period, at 4 wk postpartum, and at 8 wk postpartum.

${ }^{2} \mathrm{LS}=$ locomotion score; ObP = observation period (dry/lactation); ObM = observation moment (first/second scores); CS = calving season. 
A

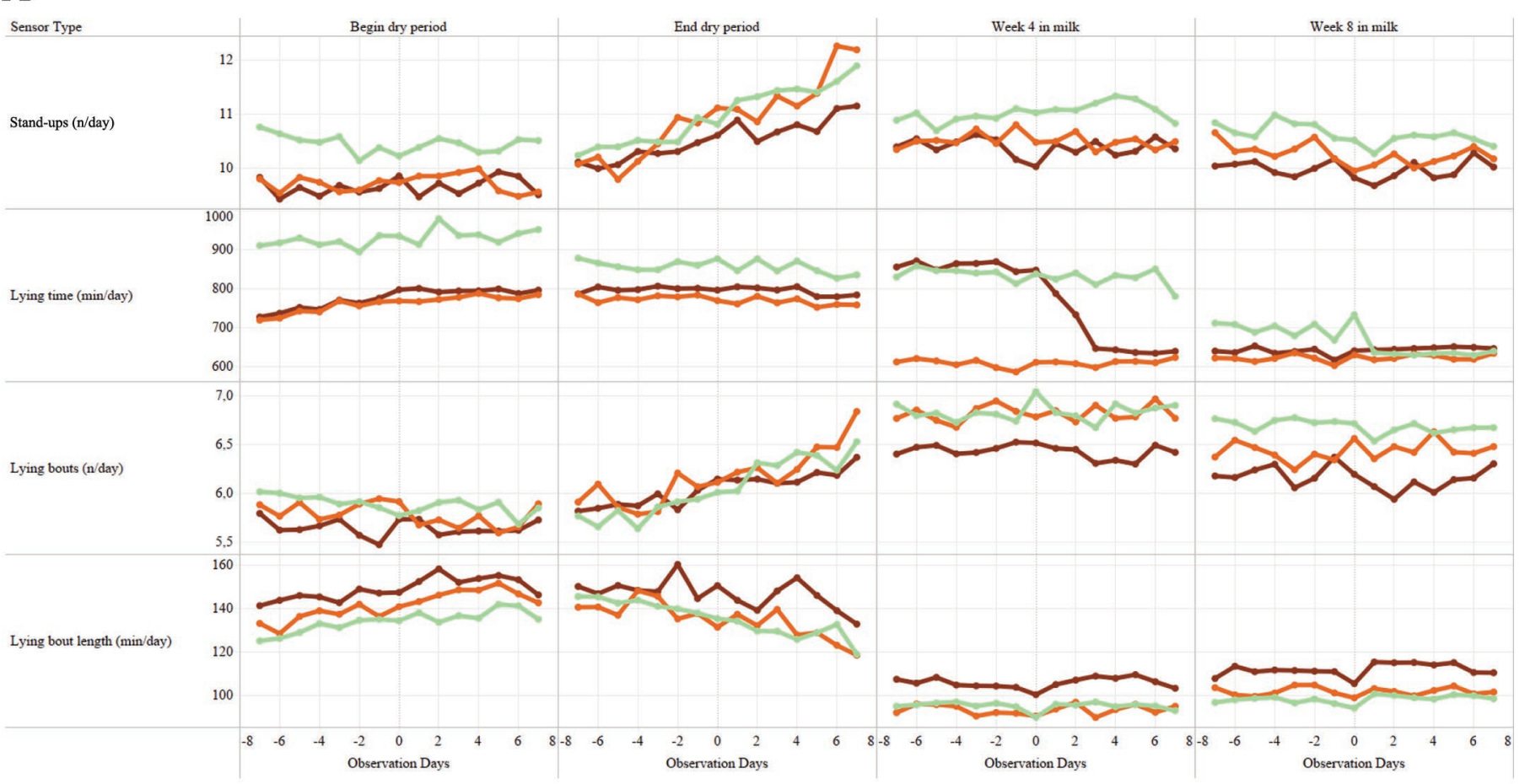

B

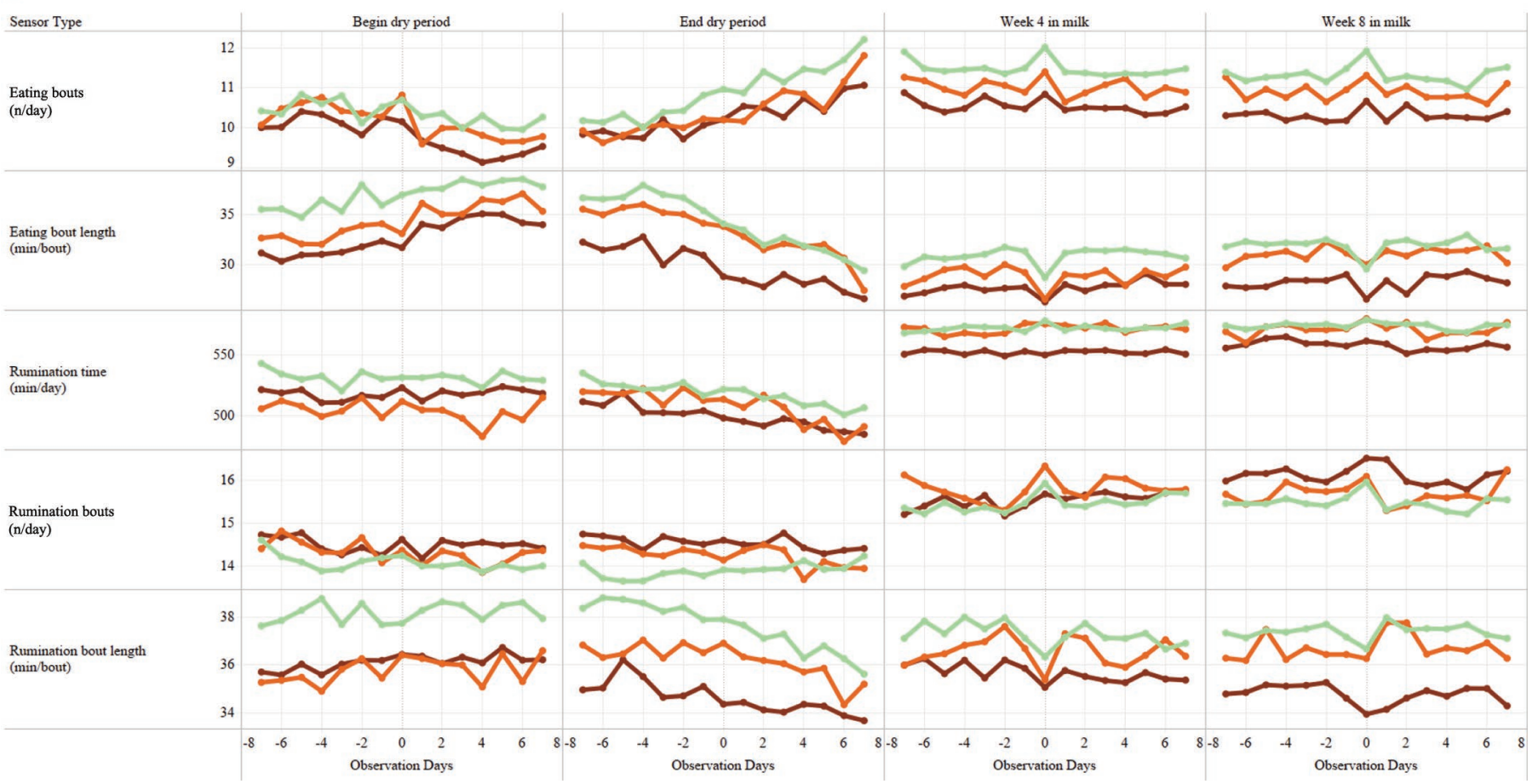

Figure A1. Descriptive values per scoring event (begin dry, end dry, 4 wk postpartum, 8 wk postpartum) and per behavioral parameter (number of stand-ups, lying time, lying bouts, lying bout length) from the leg sensor (A) and data (eating bouts, eating bout length, rumination time, rumination bouts, rumination bout length) from the neck sensor (B) in 3 locomotion scoring groups (green: nonlame; orange: moderately lame; red: severely lame) from $7 \mathrm{~d}$ before until $7 \mathrm{~d}$ after the day of scoring (d 0). Number of multiparous cows with full sensor data per locomotion score group was as follows: begin dry period, $\mathrm{n}=707$ (scores 1 and $2: \mathrm{n}=378$, score $3: \mathrm{n}=127$, scores 4 and 5: $\mathrm{n}=205$ ); end dry period, total $\mathrm{n}=717$ (scores 1 and $2: \mathrm{n}=370$, score $3: \mathrm{n}=112$, scores 4 and $5: \mathrm{n}=235$ ); 4 wk in milk, total $\mathrm{n}=755($ scores 1 and $2: \mathrm{n}=398$, score 3: $\mathrm{n}=124$, scores 4 and 5: $\mathrm{n}=233$ ); 8 wk in milk, total $\mathrm{n}=752$ (scores 1 and $2: \mathrm{n}=385$, score $3: \mathrm{n}=154$, scores 4 and $5: \mathrm{n}=213$ )]. 


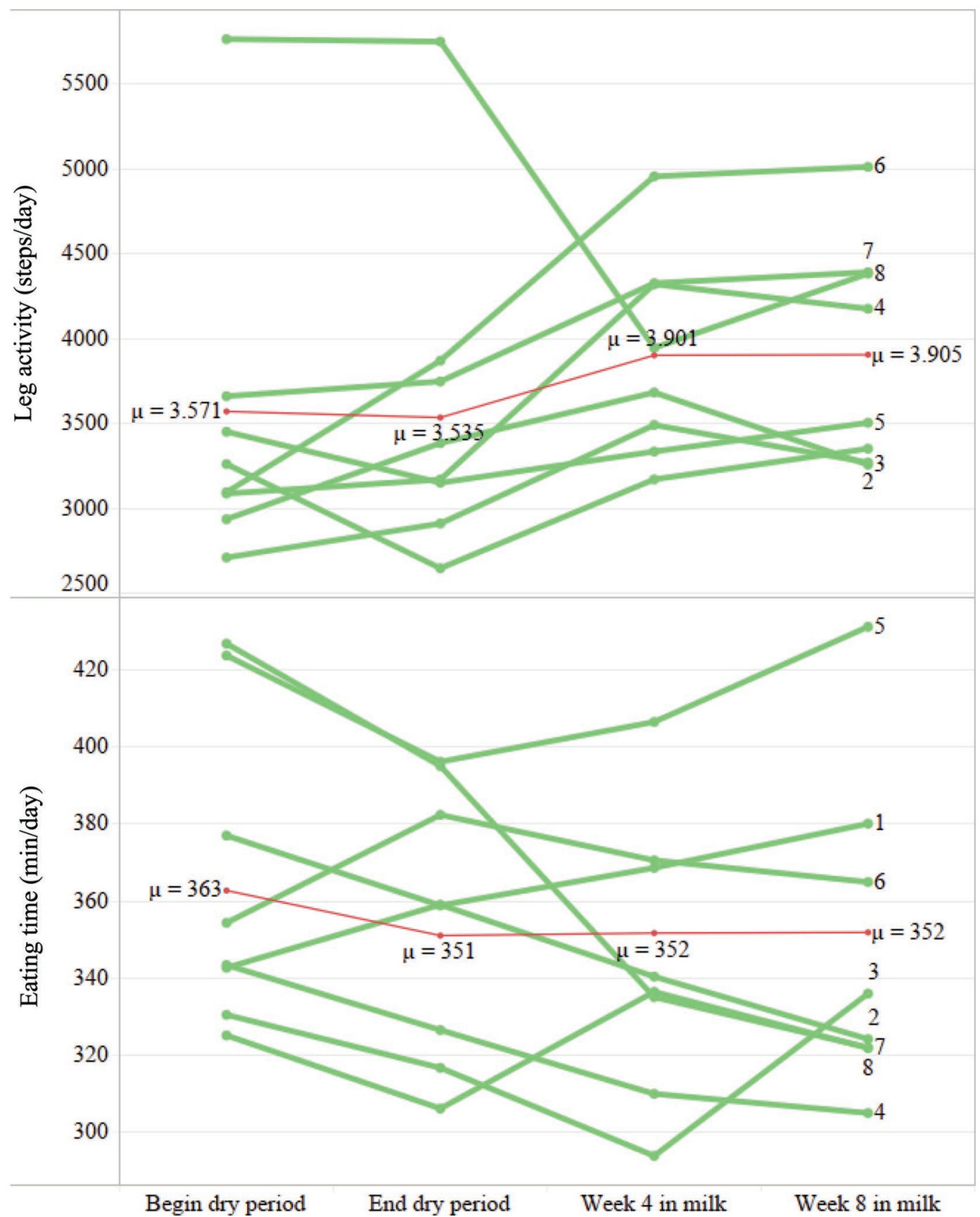

Figure A2. Descriptive values averaged per scoring event (begin dry, end dry, 4 wk postpartum, 8 wk postpartum) for locomotion scores 1 and 2 for eating time (min/d) and steps (no./d) per farm (1-8, green lines) to present farm differences and behavior differences between the pre- and postpartum periods. Mean values per scoring event are presented in red. 